\title{
Współpraca kulturalna Polski z Węgrami w dziedzinie kinematografii w latach siedemdziesiątych XX wieku
}

Zarys treści: Artykuł poświęcony jest dobrze udokumentowanym, ale rzadko analizowanym przez badaczy kontaktom kulturalnym Polskiej Rzeczypospolitej Ludowej i Węgierskiej Republiki Ludowej w dziedzinie kinematografii w latach 1971-1980. W tzw. dekadzie gierkowskiej kino madziarskie cieszyło się w Polsce dużym zainteresowaniem (zwłaszcza w środowisku krytyków i dyskusyjnych klubów filmowych), z kolei na Węgrzech wciąż panowała „moda na Polskę” i polski film. W opracowaniu uwagę skupiono na przebiegu polsko-węgierskiej współpracy filmowej w sferze koprodukcji, wymiany usług, imprez i festiwali. Ważną rolę w popularyzacji wzajemnych osiągnięć filmowych odegrały Ośrodek Informacji i Kultury Polskiej w Budapeszcie oraz Węgierski Instytut Kultury w Warszawie, a także kontakty niezależne.

Outline of content: The article is devoted to well-documented, but seldom analysed by researchers cultural contacts of the Polish People's Republic and Hungarian People's Republic in the field of filmmaking in 1971-1980. In the so-called Gierek's era, Hungarian films enjoyed great popularity and interest (especially among film critics and film societies), while in Hungary Poland and Polish movies were still "in vogue". The study focuses on the course of Polish-Hungarian film cooperation in the area of coproduction, exchange of services, events, and festivals. An important part in the popularising of film achievements was played by the Centre of Polish Information and Culture in Budapest and the Hungarian Institute of Culture in Warsaw, but also by independent contacts.

Slowa kluczowe: Polska Rzeczpospolita Ludowa, Węgierska Republika Ludowa, polityka kulturalna Polski i Węgier, polsko-węgierska współpraca kulturalna, kinematografia polska, kinematografia węgierska.

Keywords: Polish People’s Republic, Hungarian People's Republic, cultural policy of Poland and Hungary, Polish-Hungarian cultural cooperation, Polish filmmaking, Hungarian filmmaking

Historia związków filmowych pomiędzy Polską Rzecząpospolitą Ludową (PRL) i Węgierską Republiką Ludową (WRL) - krajami, których kinematografie (zresztą mocno na siebie oddziałujące) charakteryzują się bogactwem oryginalnych 
formul ${ }^{1}$ - zasługuje na wyróżnienie. Przedmiotem niniejszego artykułu są dobrze udokumentowane, ale rzadko analizowane przez badaczy kontakty obu państw w tej dziedzinie ${ }^{2}$. Cezury rozważań odnoszą się do okresu piastowania stanowiska I sekretarza Komitetu Centralnego Polskiej Zjednoczonej Partii Robotniczej (KC PZPR) przez Edwarda Gierka. Zważywszy na fakt, że w tzw. dekadzie gierkowskiej (1971-1980) kino madziarskie odniosło w Polsce swój wyjątkowy sukces artystyczny (udokumentowany $\mathrm{w}$ piśmiennictwie filmowym ${ }^{3}$ i wspominany z sentymentem po dziś dzień przez członków dyskusyjnych klubów filmowych [DKF]), a z kolei na Węgrzech panowała zrodzona w poprzedniej dekadzie „moda” na film polski (widzowie węgierscy do tej pory ciepło oceniają bardzo popularne ówcześnie seriale Stawka większa niż życie oraz Czterej pancerni i pies), wypełnienie luki badawczej wydaje się szczególnie zasadne. Głównym celem artykułu jest ukazanie w sposób syntetyczny przebiegu polsko-węgierskiej współpracy filmowej w latach siedemdziesiątych, osadzonej w specyficznym kontekście politycznym, na tle ogólnych regulacji w dziedzinie kultury. Dla zrealizowania określonego dążenia należało, jak sądzę, zastanowić się nad, po pierwsze, polityczno-historycznymi uwarunkowaniami stosunków kulturalnych (filmowych) między państwami i ich znaczeniem w relacjach dwustronnych; i po drugie, deklarowanymi i realizowanymi formami współpracy $\mathrm{w}$ dziedzinie kinematografii. Aby je odzwierciedlić, analizą objęto, poza dostępną $\mathrm{w}$ obiegu naukowym literaturą przedmiotu, prasę specjalistyczną oraz dokumenty archiwalne.

W dekadzie Edwarda Gierka sytuacja międzynarodowa przedstawiała się dla Polski korzystnie. Nowej ekipie sprzyjało złagodzenie napięcia w stosunkach Wschód - Zachód, umożliwiające rozszerzenie kulturalnych kontaktów z zagranicą. Jednocześnie dążono do „umacniania przyjaźni” i „zacieśnienia współpracy” z krajami socjalistycznymi ${ }^{4}$. Polska podtrzymywała dobre relacje z Węgrami, które

${ }^{1}$ Chodzi o polską szkołę filmową, kino moralnego niepokoju i węgierską nową falę. Zob. też: A. Horoszczak, A.M. Rutkowski, Film wegierski w Polsce, Warszawa 1981, s. 24.

2 Poza kilkoma opracowaniami (m.in. Z. Biegańskiego, Kino puli specjalnej. Filmy jugosłowiańskie na ekranach kin Polski Ludowej, w: Polska i Jugosławia w stosunkach międzynarodowych po II wojnie światowej. Relacje wielostronne i wielopoziomowe, red. M. Pavlović, A. Zaćmiński, Bydgoszcz 2014, i J. Szczutkowskiej, Współpraca kulturalna Polski z Jugosławia $w$ dziedzinie kinematografii w latach siedemdziesiątych XX wieku, w: Polska i Jugosławia po II wojnie światowej, red. M. Pavlović, N. Stambolija, A. Zaćmiński, Bydgoszcz 2016), brakuje aktualnej historycznej monografii współpracy filmowej PRL z zagranicą. W tym miejscu warto zwrócić uwagę na osiągnięcia polskich filmoznawców w zakresie powiązań kinematografii narodowych, a wśród nich zwłaszcza: Polska i Niemcy. Filmowe granice i sąsiedztwa, red. K. Klejsa, Wrocław 2012; W drodze do sąsiada. Polsko-niemieckie spotkania filmowe, red. A. Dębski, A. Gwóźdź, Wrocław 2013; Polsko-włoskie kontakty filmowe. Topika, koprodukcje, recepcja, red. A. Miller-Klejsa, M. Woźniak, Łódź 2014.

3 Szerzej na temat recepcji kina węgierskiego w polskiej powojennej krytyce filmowej zob. P. Zwierzchowski, The reception of Hungarian cinema in Polish film criticism 1945-1989, w: History of European Cinema. Intercultural Perspective, red. B. Zając, M. Pabiś-Orzeszyna, M. Dondzik, Łódź 2015, s. 79-90.

4 A. Skrzypek, Dyplomatyczne dzieje PRL w latach 1956-1989, Pułtusk-Warszawa 2010, s. 189, 194, 238-239, 272; J. Zając, R. Zięba, Polska w stosunkach międzynarodowych 1945-1989, Toruń 2005, 
w świadomości powszechnej utrwaliły się historyczną braterską i szczerą przyjaźnią ${ }^{5}$. W oficjalnych źródłach polsko-węgierskie stosunki bilateralne ocenia się pozytywnie i zaznacza, że od 1972 r. uległy one zauważalnemu ożywieniu. Zarówno Gierek, jak i I sekretarz KC Węgierskiej Socjalistycznej Partii Robotniczej (WSPR) János Kádár nadawali im duże znaczenie i przywiązywali wagę do ich dalszego rozwoju6 ${ }^{6}$ W tym miejscu trzeba zaznaczyć, że okres zimnej wojny, o którym traktuje niniejszy tekst, odznaczał się dualistycznym spojrzeniem na wyjątkową więź łączącą „bratanków” znad Wisły i Dunaju. Dwoistość ta uwidaczniała się w stanowisku władz, które próbowały interpretować ją w kategoriach internacjonalistycznych, oraz $\mathrm{w}$ pamięci zbiorowej, przenikającej oficjalny sposób pojmowania tych wielowiekowych kontaktów. Tradycyjną sympatię kumulowały peryferia i życie kulturalne, rozwijające się w ramach specyficznego komunistycznego mechanizmu kooperacji w tej dziedzinie ${ }^{7}$. Stąd, pielęgnowanie pamięci o wspólnych przeżyciach i wymianę doświadczeń umożliwił m.in. - odnosząc się do tematu określonego w tytule - rozwój szeroko rozumianej kultury filmowej.

s. 128-129; E. Cziomer, Polityka odprężenia Wschód - Zachód w latach 70. i 80., w: Międzynarodowe stosunki polityczne, red. idem, Kraków 2008, s. 173-174; W. Jarząbek, Polska wobec Konferencji Bezpieczeństwa i Wspótpracy w Europie. Plany i rzeczywistość 1964-1975, Warszawa 2008, s. 7.

${ }^{5} \mathrm{~W}$ taki sposób utrwaliły się również w polskiej literaturze. Dla przykładu, Judit Reiman, opisując tradycyjnie życzliwe stosunki pomiędzy Polakami i Węgrami z perspektywy lat dziewięćdziesiątych XX w. stwierdziła: „Poważniejsze konflikty nigdy dotąd nie zakłóciły wyjątkowo trwałej i obopólnej sympatii, jaką czują do siebie te dwa narody, sympatii dalekiej od oportunizmu politycznego" J. Reiman, Węgierskie postrzeganie Polaków w latach osiemdziesiątych, w: Narody i stereotypy, red. T. Walas, Kraków 1995, s. 64. O „autentyczności i prawdziwości polsko-węgierskiej przyjaźni” pisze też Tadeusz Kaczor w szkicu pt. Przyjaźń z tysiącletnim rodowodem, w: Przyjaźń z tysiącletnim rodowodem. Szkice $z$ dziejów relacji polsko-wegierskich, red. P. Jakóbczyk-Adamczyk, D. Rogut, Bełchatów 2009, s. 236. Z kolei Jerzy Szablowski w Słowie wstępnym publikacji W. Felczaka i A. Fischingera pt. Polska - Węgry, tysiąc lat przyjaźni, Budapeszt-Warszawa 1979, zaakcentował wyjątkowość więzi pomiędzy tymi narodami na tle historii stosunków międzynarodowych: „Serdeczna przyjaźń i wielka sympatia, stanowiące - rzec można - przewodni motyw tysiącletnich związków polsko-węgierskich, zgoła niespotykane w stosunkach międzynarodowych, zwłaszcza między państwami o wspólnej przez tyle wieków granicy, były i są szeroko znane i podziwiane, tym bardziej iż zachowują nadal pełną żywotność i znaczenie".

${ }^{6}$ Notatka z rozmowy I Sekretarzy KC PZPR i KC WSPR tow. tow. E. Gierka z J. Kádárem przeprowadzonej w dniu 15.03.1973 r., w: Polskie dokumenty dyplomatyczne 1973, red. P.M. Majewski, Warszawa 2006, s. 128; Pilna notatka $z$ oficjalnej wizyty członka KC WSPR i Ministra Spraw Zagranicznych WRL Jánosa Pétera w Polsce w dniach 5-7 września 1973 r., w: ibidem, s. 459, 462-463. Zob. też: E.J. Pałyga, Dyplomacja Polski Ludowej 1944-1984. Kierunki - treści-mechanizmy, Warszawa 1986, s. 102; E. Podbierowa, Stosunki między Polska a Wegrami, w: Stosunki Polski z innymi państwami socjalistycznymi, red. Cz. Mojsiewicz, Warszawa 1973, s. $106 \mathrm{n}$.

7 Á. Engelmayer, Echo, pamięć i rola rewolucji wegierskiej 1956 r. w polskich publikacjach prasowych $i$ książkowych drugiego obiegu (wydawanych nielegalnie) w latach siedemdziesiatych i osiemdziesiątych, w: Polskie lato, węgierska jesień. Polsko-węgierska solidarność w latach 1956-1990, red. C. Kiss Gy., K. Sutarski, Budapeszt 1997, s. 59; T. Kopyś, Stosunki polsko-węgierskie w latach 1945-1970, Kraków 2015, s. 10; C. Kiss Gy., Pielęgnacja tradycji przyjaźni polsko-węgierskiej jako jedna z form opozycyjności (pytania i przybliżenia), w: Polskie lato, węgierska jesień..., s. 24, 26. 
Kultura, w której partia i państwo upatrywały ważnego instrumentu polityki zagranicznej, integrującego kraje socjalistyczne, okazała się wartościową płaszczyzną współpracy ${ }^{8}$. Niewątpliwy wpływ na wyobrażenia zbiorowe i charakter polsko-węgierskich stosunków międzypaństwowych w latach siedemdziesiątych miały bogate wielowiekowe tradycje kulturowe ${ }^{9}$. Dążono do rozszerzania różnorodnych form współpracy kulturalnej, będącej w kontekście regulacji prawnych swoistą kontynuacją porozumień zawartych po II wojnie światowej. Ich podstawę stanowiła Konwencja kulturalna między Rzecząpospolitą Polską a Republiką Węgierską podpisana 31 stycznia $1948 \mathrm{r}$. w Budapeszcie ${ }^{10}$. W artykule 7 obie strony zobowiązały się rozwijać współpracę między instytucjami filmowymi. Konwencję tę zastąpiono następnie Umową o współpracy kulturalnej i naukowej, podpisaną w Warszawie 31 października 1968 r. Ratyfikowana przez obie strony (przez Radę Państwa PRL 18 czerwca 1969 r.), weszła w życie 13 lutego 1970 r. ${ }^{11}$ W dziedzinie kinematografii zadeklarowano regularną współpracę oraz wymianę specjalistów. Umawiające się strony stwierdziły, że będą popierać koprodukcje filmów i ich rozpowszechnianie, a także uczestnictwo $\mathrm{w}$ ważniejszych artystycznych imprezach (art. 7 i 8). Nową umowę, zawartą, jak uzasadniano w jednej z oficjalnych notatek, ze względu na systematycznie zwiększające się rozmiary wymiany ${ }^{12}$, urzeczywistniano dzięki rocznym (w 1973 r.) i dwuletnim (w latach 1969-1972 oraz 1974-1975) planom realizacji umowy kulturalnej i naukowej. Natomiast w drugiej połowie lat siedemdziesiątych współpracę regulował Plan realizacji umowy kulturalnej i naukowej między PRL i WRL na lata 1976-1980, podpisany 23 stycznia 1976 r. w Warszawie ${ }^{13}$. Zawarte w tym dokumencie postanowienia realizowano na podstawie bezpośrednich kontaktów, porozumień i planów roboczych między ministerstwami, centralnymi instytucjami, związkami twórczymi oraz organizacjami

8 J. Kossak, Rozwój kultury w Polsce Ludowej, Warszawa 1974, s. 14; Węzłowe kierunki i zadania polityki zagranicznej PRL w 1979 roku, w: Polskie dokumenty dyplomatyczne 1979, red. P. Długołęcki, J. Kochanowski, Warszawa 2014, s. 22-23.

9 Na znaczenie tradycji kulturowych w analizie stosunków między państwami zwrócił uwagę Franciszek Gołembski, pisząc, że wpływają one na świadomość społeczną i aktualny charakter relacji dwustronnych - F. Gołembski, Współpraca kulturalna w procesie budowy europejskiego ładu pokojowego, Warszawa 1979, s. 199-200. Szerzej na temat polsko-węgierskich tradycji kulturowych, sięgających czasów średniowiecza, zob. np. Studia $z$ dziejów polsko-węgierskich stosunków literackich i kulturalnych, red. J. Reychman, I. Csapláros, A. Sieroszewski, Wrocław 1969; Studia z dziejów polsko-węgierskich stosunków literackich, red. István Csapláros, Warszawa 1978.

10 Dziennik Ustaw (dalej: DzU) 1948, nr 51, poz. 399, http://dokumenty.rcl.gov.pl/DU/rok/1948/ wydanie/51/pozycja/399 (dostęp: 18.01.2016); T. Kopyś, op. cit., s. 99 n.

11 DzU 1970, nr 8, poz. 64, http://dziennikustaw.gov.pl/DU/1970/s/8/64 (dostęp: 18.01.2016); B. Płaza, Kultura zbliża narody. O wspótpracy kulturalnej Polski z zagranica w latach 1945-1976, Warszawa 1978, s.177-178.

12 Archiwum Ministerstwa Spraw Zagranicznych (dalej: AMSZ), Departament Prasy, Współpracy Kulturalnej i Naukowej (dalej: DPWKN) 13/83, Węgry 1978, Notatka. Dot. pisma DIWK-WRL-217-1-74 dyr. Klaczyńskiego. Opracował: Wincenty Mroczkowski.

13 B. Płaza, op. cit., s. 178. 
społecznymi uczestniczącymi w wymianie kulturalnej ${ }^{14}$. Mając za podstawę plan realizacji umowy o współpracy kulturalnej na lata 1976-1980, Ministerstwo Kultury i Sztuki PRL i Ministerstwo Kultury WRL uzgodniły i podpisały Protokół wykonawczy na lata 1978-1980, przedstawiający dokładny program dalszej współpracy ${ }^{15}$. Uwzględniając jej wyniki, kolejną Umowę między rządami o współpracy kulturalnej i naukowej podpisano w Warszawie 9 lipca 1980 r. ${ }^{16}$ Realizowanie postanowień zawartych w dokumencie zbiegło się z okresem zrywu społecznego i stanu wojennego, kiedy to atrofii uległy oficjalne międzynarodowe kontakty Polski z zagranicą w dziedzinie kultury i sztuki ${ }^{17}$.

„Tradycyjna przyjaźń” wzmocniona prawnym instrumentarium stworzyła podatny grunt do rozwoju współpracy $\mathrm{w}$ dziedzinie kinematografii ${ }^{18}$. W omawianym czasie filmowa kooperacja Polski z zagranicą stanowiła istotny element międzynarodowej działalności kulturalnej. Służąc celom politycznym, informacyjnym i handlowym, zakładała zasięg globalny, przy czym koncentrowano się na umacnianiu kontaktów z europejskimi krajami socjalistycznymi. Specjalne

14 AMSZ, DPWKN 13/83, Węgry 1978, Plan realizacji Umowy o Współpracy Kulturalnej i Naukowej między Rządem Polskiej Rzeczypospolitej Ludowej i Rządem Węgierskiej Republiki Ludowej na lata 1976-1980. Rozwiązaniom przyjętym w planie na lata 1976-1980 przysłużyły się niewątpliwie ustalenia podjęte w czasie pobytu w dniach od 17 do 21 listopada 1975 r. w Budapeszcie przedstawicieli Polsko-Węgierskiej Komisji Mieszanej do Spraw Współpracy Kulturalnej i Naukowej. W jej składzie znaleźli się m.in. przewodniczący sekcji polskiej Komisji Mieszanej - podsekretarz stanu Tadeusz Kaczmarek oraz radca Ambasady PRL w Budapeszcie Czesław Kowal. Z przedstawicielami PRL spotkali się wówczas m.in. wiceminister kultury Imre Pozsgay oraz przewodniczący węgierskiej sekcji Komisji Mieszanej - sekretarz stanu Ferenc Molnár. Delegację przyjął minister kultury László Orbán. Polski podsekretarz stanu spotkał się ponadto z członkiem Biura Politycznego i sekretarzem KC Miklósem Óvárim, który wyraził przekonanie, że „rozwój wymiany kulturalnej z Polską następuje nie tylko w związku z sytuacją międzynarodową, ale również z uwagi na sytuację wewnętrzną, z potrzeby węgierskiej, wewnętrznej polityki kulturalnej”. Pobyt na Węgrzech oceniono jako bardzo udany i dający nadzieje na kolejne rozwojowe pięciolecie w polsko-węgierskich stosunkach kulturalnych. Obie strony za celowe uznały „dalsze zwiększenie efektywności przy utrzymaniu wysokiego poziomu współpracy kulturalnej między krajami socjalistycznymi”, a w jej ramach, „Z uwagi na tradycyjną przyjaźń”, szczególną rolę powinny odgrywać stosunki PRL-WRL, AMSZ, DPWKN 13/83, Węgry 1978, Notatka z rozmów delegacji polskiej w czasie pobytu w Budapeszcie w dniach 17-21.11.1975.

15 AMSZ, DPWKN 13/83, Węgry 1978, Ocena stanu realizacji 5-letniego Planu Współpracy Kulturalnej i Naukowej pomiędzy PRL i WRL.

16 DzU 1981, nr 19, poz. 91, http://www.dziennikustaw.gov.pl/DU/1981/s/19/91 (dostęp: 18.01.2016); AMSZ, DPWKN 13/83, Węgry 1978, Uzasadnienie wniosku o ratyfikację Umowy między Rządem Polskiej Rzeczypospolitej Ludowej a Rządem Węgierskiej Republiki Ludowej o współpracy kulturalnej i naukowej (projekt); ibidem, Umowa między Rządem Polskiej Rzeczypospolitej Ludowej a Rządem Węgierskiej Republiki Ludowej o współpracy kulturalnej i naukowej. Na temat podstaw prawnych zob. też: J. Szczutkowska, „Żywotność i znaczenie” - wspótpraca kulturalna Polski $z$ Wegrami w latach 70. XX wieku, w: Historia kluczem do zrozumienia współczesnych relacji międzysąsiedzkich, red. T. Maresz, K. Grysińska-Jarmuła, Bydgoszcz 2016, s. 431-443.

17 Z. Biegański, Kino puli specjalnej..., s. 257.

18 A. Horoszczak, A.M. Rutkowski, op. cit., s. 3. 
miejsce zajmowała, rzecz jasna, współpraca z ZSRR, a w dalszej kolejności z: Niemiecką Republiką Demokratyczną, Czechosłowacją, Bułgarią, Jugosławią, Rumunią i Węgrami ${ }^{19}$. Jak zauważa Tadeusz Kopyś, znawca stosunków polsko-węgierskich, film i kinematografia okazały się płaszczyzną kultury i sztuki, która najszybciej połączyła Polskę i Węgry po II wojnie światowej. Na przestrzeni dekad temperatura międzypaństwowych związków w tej dziedzinie ulegała jednak zmianom. Po 1956 r. ciekawie zapowiadająca się współpraca została zminimalizowana $^{20}$. Niekorzystną rolę odegrała ekspansja propagandowa Węgier, dążących do tego, aby nie dopuścić do życia kulturalnego zjawisk obserwowanych w Polsce „popaździernikowej”. Niektórzy działacze WSPR posądzali kierownictwo PZPR o tolerowanie „szkodliwych prądów w kulturze"21. W opracowaniu Ambasady PRL w Budapeszcie z 17 sierpnia 1958 r. zwrócono uwagę, że wedle ocen węgierskiego resortu kultury „film nasz przeżywa krytyczny okres jakiejś degrengolady pod wpływem zachodniej sztuki dekadencji”22. Z takim podejściem wiązała się decyzja o odrzuceniu wielu filmów wyprodukowanych nad Wisłą i niechęć do zapraszania artystów, których styl bycia kojarzył się z amerykańskim, takich jak Zbigniew Cybulski (którym notabene węgierscy miłośnicy polskiej szkoły filmowej byli zafascynowani $\left.{ }^{23}\right)$. Z czasem wskazane trendy przestały niepokoić węgierskie kierownictwo partyjne. W kontekście stosunków filmowych pewnym przełomem okazała się wizyta w Budapeszcie w maju 1967 r. ministra kultury i sztuki Lucjana Motyki, kiedy to podjęto temat realizacji wspólnych przedsięwzięć i koprodukcji ${ }^{24}$.

W latach siedemdziesiątych współpracę filmową określały porozumienia podpisywane przez Naczelne Zarządy Kinematografii (NZK) Ministerstwa Kultury i Sztuki PRL i Ministerstwa Kultury WRL na okres dwóch lat. Dążąc do rozwoju kooperacji, zakładano wielość jej form, obejmujących następujące działania:

- wspólna realizacja filmów fabularnych i krótkometrażowych;

- współpraca w zakresie świadczenia usług;

- wymiana filmowców, techników, specjalistów od spraw rozpowszechniania, aktorów i dziennikarzy;

- organizowanie uroczystych premier tzw. filmów o wysokich walorach ideowo-artystycznych („wybitnych”) z udziałem twórców;

- organizowanie raz w roku imprez filmowych („Dni Filmu”, retrospektywy itp.) wspólnych oraz na zasadzie wzajemności;

19 Archiwum Akt Nowych (AAN), Naczelny Zarząd Kinematografii (NZK), sygn. 1/109, Perspektywiczny program działania polskiej kinematografii za granicą. Zob. też J. Szczutkowska, Polityka kulturalna PRL $w$ dziedzinie kinematografii w latach 70., Bydgoszcz 2014, s. 256-330.

20 T. Kopyś, op. cit., s. 184.

${ }^{21}$ R. Skobelski, Polityka PRL wobec państw socjalistycznych w latach 1956-1970. Wspótpraca napięcia - konflikty, Poznań 2010, s. 74.

22 Cyt. za: M. Sirecka-Wołodko, Zagraniczna polityka kulturalna Polski w latach 1956-1970, Toruń 2011, s. 200, przyp. 253.

${ }^{23}$ J.R. Nowak, Wegry bliskie i nie znane, Warszawa 1980, s. 319-320.

${ }^{24}$ T. Kopyś, op. cit., s. 89, 184, 240, 251-252, 254-255. 
- udział w festiwalach filmowych organizowanych przez kinematografie obu krajów;

- informacja wzajemna na temat uczestnictwa w międzynarodowych festiwalach, targach i innych imprezach filmowych;

- współpraca archiwów filmowych: Filmoteki Polskiej i Magyar Filmtudományi Intézet és Filmarchívum;

- wymiana materiałów i wystaw plakatu filmowego;

- wymiana aktualnych materiałów do kronik filmowych;

- fachowa informacja o aktualnym stanie twórczości filmowej polskiej lub węgierskiej w prasie codziennej obu krajów;

- wymiana doświadczeń między Stowarzyszeniem Filmowców Polskich (SFP) i Związkiem Węgierskich Artystów Filmowych i Telewizyjnych (w ramach spotkań twórców, dyskusji itp.) ${ }^{25}$.

Rozwojowi międzypaństwowych kontaktów sprzyjały spotkania międzynarodowe, a zwłaszcza doroczne narady szefów kinematografii krajów socjalistycznych ${ }^{26}$. Według Mieczysława Wojtczaka, szefa kinematografii polskiej w latach 1973-1977, ich znaczenie było nie do przecenienia. W swoich wspomnieniach zanotował: „Spotkania te służyły wymianie poglądów i informacji o produkcji oraz uzgodnieniom warunków współpracy. Miały one też wpływ na lepsze kontakty z ministrami Związku Radzieckiego, Węgier, Czechosłowacji i Bułgarii. Jak się później okazało, procentowało to pewnym zrozumieniem przez nich sytuacji, gdy u nas zaczęły powstawać «niekochane» filmy współczesne"27. Gospodarzem jednej z narad szefów kinematografii krajów socjalistycznych była Warszawa. Na zjazd, który odbył się w dniach od 11 do 12 lutego 1975 r., przybyli dyrektorzy generalni kinematografii WRL István B. Szabó (w 1978 r. ambasador PRL na Węgrzech, Tadeusz Pietrzak, uhonorował go odznaką Zasłużony dla Kultury Polskiej ${ }^{28}$ ) oraz István Kondor. Naradzie przewodniczył wiceminister kultury i sztuki Mieczysław Wojtczak ${ }^{29}$. Kształtowaniu współpracy służyły także spotkania delegatów na forum organizacji międzynarodowych, przy okazji znaczących międzynarodowych festiwali filmowych i imprez specjalistycznych, np. targów. Ważną rolę odgrywały kontakty między filmotekami oraz stowarzyszeniami filmowców. W 1974 r. w Warszawie zorganizowano spotkanie pracowników filmotek krajów socjalistycznych, w którym

25 AMSZ, DPWKN 13/83, Węgry 1978, Plan realizacji Umowy o współpracy kulturalnej i naukowej między Rządem Polskiej Rzeczypospolitej Ludowej i Rządem Węgierskiej Republiki Ludowej na lata 1976-1980; ibidem, Notatka. Dot. pisma DIWK-WRL-217-1-74...; Kronika wydarzeń, „Filmowy Serwis Prasowy” 1971, nr 11, s. 1; AMSZ, DPWKN 13/83, Węgry 1978, Protokół III posiedzenia Polsko-Węgierskiej Komisji Mieszanej ds. Współpracy Kulturalnej i Naukowej; Kronika, „Filmowy Serwis Prasowy” 1979, nr 14, s. 25.

${ }^{26}$ E. Zajiček, Film polski. Ekonomika i organizacja produkcji, Warszawa 1983, s. 100.

27 M. Wojtczak, Kronika nie tylko filmowa, Warszawa 2004, s. 196.

${ }^{28}$ Kronika, „Filmowy Serwis Prasowy” 1979, nr 1, s. 23.

29 AMSZ, DPWKN 13/83, Węgry 1978, Protokół III posiedzenia Polsko-Węgierskiej Komisji Mieszanej...; J. Szczutkowska, Polityka kulturalna PRL..., s. 280-281. 
wzięli udział Węgrzy ${ }^{30}$. Z kolei w 1978 r. odbyła się w Warszawie zorganizowana przez SFP narada przewodniczących stowarzyszeń i związków filmowców krajów socjalistycznych, z udziałem Węgier ${ }^{31}$.

Nad kierunkami i jakością filmowej kooperacji debatowano w czasie posiedzeń Polsko-Węgierskiej Komisji Mieszanej do spraw Współpracy Kulturalnej i Naukowej, powołanej do życia porozumieniem z 4 września $1972 \mathrm{r}^{32}$ Jednym z rezultatów obrad było zalecenie wydane przedstawicielom NZK, aby podczas corocznych zjazdów, mających na celu ocenę realizacji bezpośrednich dwuletnich porozumień, zwracali szczególną uwagę na stan wzajemnych zakupów filmów i ich rozpowszechniania. Zarządzono doroczne spotkania weryfikujące decyzje komisji zakupów filmów w sytuacji odrzucenia przez nie filmów o tzw. wysokich walorach ideowo-artystycznych ${ }^{33}$. Odnośnie do kwestii wzajemnych zakupów filmów i ich rozpowszechniania, na podstawie dostępnych opracowań wiadomo, że w omawianej dekadzie do kin trafiała, na zasadzie wzajemności, większość filmów wyprodukowanych w Polsce i na Węgrzech. W raporcie $\mathrm{z}$ realizacji 5-letniego planu współpracy kulturalnej stwierdzono, że „najwartościowsze filmy obu krajów były wzajemnie zakupione i udostępnione odbiorcom w kinach i telewizji" ${ }^{34}$. Węgrzy dokonywali każdego roku zakupu przeciętnie 10 filmów fabularnych do kin i największą popularnością cieszyły się dzieła Andrzeja Wajdy ${ }^{35}$.

Dla ówczesnych węgierskich historyków filmu i krytyków filmowych popularność tego reżysera była fenomenem społecznym, który mógł tłumaczyć jego stosunek do przeszłości. István Nemeskürty napisał: „Ciekawe, że twórczość żadnego $\mathrm{z}$ pozostałych, naprawdę wybitnych i cenionych [...] reżyserów polskich nie wywarła takiego wrażenia na szerokich masach widzów, jak filmy Andrzeja Wajdy. Przyczyn tego możemy chyba dopatrywać się w jego widzeniu historii, w pełnej miłości ocenie dziejów swojej ojczyzny. Jest to postawa charakterystyczna również dla węgierskich reżyserów i pisarzy”36. Z kolei Gergely Bikácsy

30 J. Szczutkowska, Polityka kulturalna PRL..., s. 282.

31 Kronika, „Filmowy Serwis Prasowy” 1979, nr 2, s. 25.

32 B. Płaza, op. cit., s. 127, 178.

33 AMSZ, DPWKN 13/83, Węgry 1978, Protokół III posiedzenia Polsko-Węgierskiej Komisji Mieszanej... Wątek ten zasługuje moim zdaniem na uwagę, jednak wymaga osobnych badań. Ze zgromadzonych dotąd materiałów wiadomo, że w 1974 r. nie zaistniała potrzeba weryfikacji decyzji komisji zakupów filmów - AMSZ, DPWKN, 13/83, Węgry 1978, Sprawozdanie z realizacji zaleceń dot. współpracy między PRL i WRL w dziedzinie kinematografii, przyjętych na III posiedzeniu Komisji Mieszanej Polsko-Węgierskiej ds. Współpracy Kulturalnej i Naukowej.

34 AMSZ, DPWKN 13/83, Węgry 1978, Ocena stanu realizacji 5-letniego Planu Współpracy Kulturalnej...; P. Pap, O wzajemnych kontaktach kinematografii polskiej i wegierskiej, w: Polska i Węgry w kulturze i cywilizacji europejskiej, red. J. Wyrozumski, Kraków 1997, s. 348.

35 AMSZ, DPWKN 13/83, Węgry 1978, Protokół posiedzenia Zespołu ds. Informacji i Propagandy przy Ambasadzie PRL w Budapeszcie, odbytego w dniu 23.01.1978.

36 I. Nemeskürty, Historia filmu wegierskiego, Warszawa 1979, s. 9. 
w wydanej w 1975 r. monografii Andrzej Wajda. Szemtöl szemben stwierdził, że widz węgierski udowodnił, „że filmy Wajdy są prawdziwie zrozumiałe”37. Pokazom filmów Wajdy nadawano nierzadko uroczystą oprawę, jak w październiku 1979 r., kiedy to projekcja Panien $z$ Wilka uświetniła Dni Warszawy w Budapeszcie ${ }^{38}$. Jego twórczości poświęcano też szczególną uwagę w prasie węgierskiej. Na ok. 30 recenzji i materiałów o kinie polskim opublikowanych w 1977 r. z największym zainteresowaniem przyjęto dzieła: Ziemia obiecana, Smuga cienia oraz Człowiek $z$ marmuru $^{39}$. Ziemia obiecana była najczęściej wyświetlanym filmem w kinach w Budapeszcie w 1977 r. - zorganizowano ponad 450 seansów (zob. tabela 1). Z kolei entuzjastyczne przyjęcie Człowieka z marmuru na Węgrzech (recenzje zamieścił m.in. tygodnik kulturalny „Új tükör” oraz „Filmvilág”) zwróciło uwagę polskich publicystów. Dla Jerzego Roberta Nowaka taka reakcja w porównaniu $\mathrm{z}$ trudnymi losami tego dzieła w Polsce ${ }^{40}$ stanowiła dowód na gotowość węgierskich polityków kulturalnych do przyjęcia nowych idei. Z polskiego punktu widzenia tamtego okresu walorem kinematografii WRL, która notabene tak samo jak rodzima borykała się z rozmaitymi problemami ${ }^{41}$, była otwartość na różne tematy. W tym kontekście istotne znaczenie miała decyzja ministra kultury WRL Imre Pozsgaya, który w 1977 r. sprzeciwił się „oportunistycznej postawie unikania ryzyka” i rozszerzył repertuar sprowadzanych filmów. Postanowiono zweryfikować niektóre decyzje komisji zakupów filmów, skutkujące odrzuceniem w przeszłości wielu wartościowych dzieł. Efekty nowej strategii władz obrazuje tabela 1, z której wynika, że wśród najczęściej wyświetlanych polskich filmów na węgierskich ekranach w 1977 r. znalazły się te wyprodukowane nawet wiele lat wcześniej ${ }^{42}$.

37 G. Bikácsy, Andrzej Wajda. Szemtöl szemben, Budapest 1975. Cyt. za: J.R. Nowak, Wegry bliskie..., s. 320.

38 Kronika, „Filmowy Serwis Prasowy” 1979, nr 23, s. 25.

39 AMSZ, DPWKN 13/83, Węgry 1978, Uwagi o polsko-węgierskiej współpracy kulturalnej i naukowej w $1977 \mathrm{r}$.

${ }^{40} \mathrm{Na}$ temat problemów władz PRL z filmem Człowiek $z$ marmuru pisze ówczesny minister kultury Józef Tejchma w swoich dziennikach, Kulisy dymisji. Z dzienników ministra kultury 1974-1977, Kraków 1991, s. 229-230, 234-235, 243-249. Zob. też: D. Dabert, Kino moralnego niepokoju. Wokót wybranych problemów poetyki i etyki, Poznań 2013, s. 219-230; A. Misiak, Kinematograf kontrolowany. Cenzura filmowa w kraju socjalistycznym i demokratycznym (PRL i USA). Analiza socjologiczna, Kraków 2006, s. 297-299.

41 J.R. Nowak, Uparty rozrachunek, „Kino” 1981, nr 6, s. 32. Ówczesne problemy kinematografii węgierskiej dostrzegała polska prasa - P. Zwierzchowski, op. cit., s. 86. Szerzej na temat problemów organizacyjnych kinematografii węgierskiej zob. też J.R. Nowak, Polityka kulturalna WSPR w latach 1968-1977, Warszawa 1978, s. 118-121; Cultural policy in Hungary. A survey prepared under the auspices of the Hungarian National Commission for Unesco, Paris 1974, s. 55-56. $\mathrm{Z}$ kolei na temat organizacji i funkcjonowania w tym okresie kinematografii polskiej zob. prace najwybitniejszego w Polsce badacza specjalisty Edwarda Zajička. Spośród licznych dzieł tego autora zob. np. Poza ekranem. Kinematografia polska 1896-2005, Warszawa 2009.

42 J.R. Nowak, Uparty rozrachunek..., s. 32; idem, Polityka kulturalna WSPR..., s. 188-189. 
Tabela 1. Polskie filmy fabularne wyświetlane w kinach w Budapeszcie w 1977 r. (wybór)

\begin{tabular}{|c|c|}
\hline Tytuł [rok produkcji] & Liczba seansów \\
\hline Ziemia obiecana [1974] & 457 \\
\hline Janosik [1974] & 14 \\
\hline Znikąd donikąd [1975] & 4 \\
\hline Faraon [1965] & 32 \\
\hline Iluminacja [1972] & 2 \\
\hline Popiół i diament [1958] & 7 \\
\hline W pustyni i w puszczy [1973] & 7 \\
\hline Bilans kwartalny [1974] & 48 \\
\hline Krzyżacy [1960] & 10 \\
\hline Kardiogram [1971] & 26 \\
\hline Polowanie na muchy [1969] & 8 \\
\hline Koniec wakacji [1974] & 3 \\
\hline Pan Wołodyjowski [1969] & 3 \\
\hline Potop I i II [1973-1974] & $7+7$ \\
\hline Dzieje grzechu [1975] & 73 \\
\hline Moja wojna, moja miłość [1975] & 7 \\
\hline W środku lata [1975] & 53 \\
\hline Skazany [1975] & 34 \\
\hline Dulscy [1975] & 63 \\
\hline Krajobraz po bitwie [1970] & 2 \\
\hline Pociagg [1959] & 96 \\
\hline Linia $[1974]$ & 34 \\
\hline Zapamiętaj imię swoje (radz.-pol.) [1974] & 2 \\
\hline
\end{tabular}

Źródło: Archiwum Ministerstwa Spraw Zagranicznych, Departament Prasy, Współpracy Kulturalnej i Naukowej 13/83, Węgry 1978, Uwagi o polsko-węgierskiej współpracy kulturalnej i naukowej w 1977 r.

Zagadnienie recepcji filmu węgierskiego w Polsce w latach siedemdziesiątych zasługuje na szczególną uwagę. Od drugiej połowy lat sześćdziesiątych można zaobserwować rozkwit jego popularności i sukcesów na świecie ${ }^{43}$. Wówczas również nad Wisłę zaczęły napływać głośne dzieła przedstawicieli „nowego kina węgierskiego", takich jak: Péter Bacsó (1928-2009), István Gaál (1933-2007), Miklós Jancsó (1921-2014), András Kovács (1925-2017), István Szabó (ur. 1938)4. W kraju

43 Szerzej J.R. Nowak, Polityka kulturalna WSPR..., s. 8, 50-51.

44 A. Horoszczak, A.M. Rutkowski, op. cit., s. 4 i szerzej na temat filmu węgierskiego: I. Nemeskürty, op. cit.; Złota era kina węgierskiego. Lata 60. i 70., red. R. Kardzis, J. Topolski, Kraków 2009; J. Armata, Wegierskie kino, w: Encyklopedia kina, red. T. Lubelski, Warszawa 2010, s. 1037-1038. 
cieszącym się podobnymi tradycjami kulturalnymi, będącym kolebką nowoczesnych trendów, wyznaczonych m.in. przez Andrzeja Wajdę, Andrzeja Munka i Jerzego Kawalerowicza, w którym toczyła się podobna gra twórców z cenzurą, dzieła węgierskich artystów zostały szczególnie docenione i zrozumiane ${ }^{45}$. Każdego roku, od 1971 do końca 1980, na ekranach polskich kin gościło średnio siedem nowych filmów produkcji węgierskiej. W porównaniu z kilkudziesięcioma premierami radzieckimi ta liczba nie może imponować, jednak w zestawieniu $\mathrm{z}$ kinematografiami innych krajów bloku wschodniego, jak jugosłowiańska, statystyka wypada na korzyść Węgrów ${ }^{46}$. Spis filmów węgierskich wyświetlanych w Polsce w omawianym okresie zawiera Aneks, znajdujący się na końcu tekstu.

Uznanie krytyki i rosnące grono entuzjastów twórczości węgierskich reżyserów nie przełożyło się jednak na sukces frekwencyjny. Jak podaje Adam Horoszczak, w okresie świetności kina węgierskiego w Polsce, pomiędzy 1969 a 1974 r., zaledwie dwa razy (w 1972 i 1974) siedem tytułów (dodatkowo spoza nurtu „nowego kina węgierskiego") znalazło się w pierwszej setce najchętniej oglądanych filmów (w okresie rocznej eksploatacji) ${ }^{47}$. Niska oglądalność wiązała się z przekonaniem masowego widza o jego trudności. Z tego też powodu wiele dzieł „bratanków” aparat rozpowszechniania kierował do kin studyjnych (KS) i dyskusyjnych klubów filmowych ${ }^{48}$. Opisaną sytuację dobrze ilustruje anegdota z notatnika Andrzeja Wajdy. Pod datą 29 marca 1972 r. napisał: „Miklós Jancsó do naszego szefa kinematografii, gdy ten wspomniał o czterdziestu milionach złotych na ewentualną produkcję filmu o generale Bemie - Mnie nie można dawać tyle pieniędzy, nie ma tylu widzów, którzy chcieliby oglądać moje filmy..."49.

Polsko-węgierska współpraca filmowa przybrała wielorakie formy, przy czym - tak jak w przypadku kooperacji z innymi krajami - nade wszystko liczono na koprodukcje. Pozwalały one - nie zapominając o kwestiach ideologicznych - na rozłożenie kosztów i zwiększenie atrakcyjności filmu (dzięki zagranicznym

Zob. też prace Grzegorza Bubaka, m.in.: Twórczość filmowa Istvána Szabó, Kraków 2003; Miklós Jancsó. Obraz trudnej historii, w: Autorzy kina europejskiego VI, red. A. Helman, A. Pitrus, Warszawa 2011; Węgry, w: Kino klasyczne, red. T. Lubelski, I. Sowińska, R. Syska, Kraków 2011.

45 Nawiązuję do słów Györgyego Bárona, węgierskiego historyka filmu i krytyka, profesora filmoznawstwa w Wyższej Szkole Teatralnej i Filmowej w Budapeszcie i przewodniczącego Węgierskiego Stowarzyszenia Krytyków Filmowych - zob. idem, Wprowadzenie do perspektywy lat 60., w: Złota era kina wegierskiego..., s. 9, 11.

46 J. Szczutkowska, Polityka kulturalna PRL..., s. 295; eadem, Współpraca kulturalna Polski..., s. 302.

${ }^{47}$ Chodzi o filmy: Lew pręży się do skoku (Az oroszlán ugrani készül, reż. György Révész, 1969), Chłopcy z Placu Broni (A Pál utcai fiúk, reż. Zoltán Fábri, 1969), Gwiazdy Egeru (Egri csillagok, reż. Zoltán Várkonyi, 1968), Profesor zbrodni (Az alvilág professzora, reż. Mihály Szemes, 1969), Księżniczka czardasza (Csárdáskirálynő, reż. Miklós Szinetár, 1971), Kajtek i siedmiogłowy smok (Hahó, Öcsi!, reż. György Palásthy, Miklós Temesi, 1971), Morderca jest w domu (A gyilkos a házban van, reż. Róbert Bán, 1971).

48 A. Horoszczak, A.M. Rutkowski, op. cit., s. 5-6. Por. P. Zwierzchowski, op. cit., s. 79-80.

49 A. Wajda, Kino i reszta świata, Kraków 2000, s. 135. 
aktorom i plenerom). Historia wspólnych produkcji z krajami socjalistycznymi sięga lat pięćdziesiątych i wiąże się z realizacją polsko-czechosłowackiej komedii Jaroslava Macha pt. Zadzwońcie do mojej żony (1958). W kolejnych latach wyprodukowano wspólnie wiele filmów fabularnych, jednak głównie z ZSRR ${ }^{50}$. W przypadku Węgier rozwój tej najważniejszej formy współpracy filmowej nie mógł być dla władz zadowalający. Łącznie wskazać można zaledwie kilka filmów, przy których realizacji spotkały się obie kinematografie, i projektów, których nie udało się stworzyćc1. Przedsiębiorstwo Realizacji Filmów „Zespoły Filmowe” i Hunnia Játékfilmstúdió były producentami filmu wojennego Ferenca Kósy pt. Śnieżyca (premiera: 5.09 .1974$)^{52}$. W jego powstanie zaangażowały się także słowackie i bułgarskie studia filmowe (Filmové Studio Koliba A.S., Filmstudio Bojana). Wyrazem sympatii i więzi między narodami jest w Śnieżycy postać Polki, granej przez Polę Raksę ${ }^{53}$. Ponadto w 1975 r. zrealizowano wojenny serial telewizyjny o kurierach tatrzańskich pt. Trzecia granica (premiera: 27.01.1976). Ze strony węgierskiej zaangażowano operatora Sándora Kocsisa oraz aktorów, m.in. Gábora Sárosiego oraz Nórę Káldi. Serial wyreżyserowali Wojciech Solarz oraz Lech Lorentowicz na podstawie scenariusza Adama Bahdaja. Cztery lat później powstał film Po drodze (premiera polska: 26.05.1980) Márty Mészáros, reżyserki węgierskiej od lat związanej z Polską, która w swojej biografii Ja, Marta... z sentymentem wspomina „bratanków” i ich kino z lat siedemdziesiątych: „Lubiłam polskie filmy, znałam wielu dobrych polskich aktorów, Andrzej Wajda był moim przyjacielem, szanowaliśmy się i lubiliśmy. [...] Polska była wtedy uważana za wolny kraj, w porównaniu z nami kultura cieszyła się tam większą swobodą. Polacy kręcili podniecające filmy, istniały dobre kluby jazzowe, morze alkoholu, niemniej ludzie mówili o filmie, o teatrze, o literaturze" ${ }^{\text {" }}$. Reminiscencje Mészáros są jednym ze świadectw utrzymującej się także wśród artystów do około połowy lat siedemdziesiątych, przywołując określenie Csaby Kissa, „mody na Polskę”, będącą łącznikiem z zachodnią kulturą. Ponadto dowodzą wartości kontaktów wykraczających poza system ustalonych form i regut55. János Brendel, badacz węgiersko-polskich związków w dziedzinie

${ }^{50}$ E. Zajiček, Film polski..., s. 95-100. Na temat historii koprodukcji w tzw. bloku socjalistycznym zob. też P. Skopal, Barrandov's co-productions. The Clumsy Way to Ideological Control, International Competitiveness and Technological Improvement, w: Cinema in Service of the State. Perspectives on Film Culture in the GDR and Czechoslovakia, 1945-1960, red. L. Karl, P. Skopal, New York - Oxford 2017, s. 89-106.

51 J. Szczutkowska, Polityka kulturalna PRL..., s. 306-307.

$52 \mathrm{O}$ ile nie zaznaczono inaczej, podstawowe informacje na temat filmów i filmowców skonfrontowano $\mathrm{z}$ internetowymi serwisami filmowymi: www.imdb.com; www.filmweb.pl oraz www. filmpolski.pl.

53 „Często nawet plakatów nie było...” Rozmowa $z$ Andrzejem Wernerem o recepcji kina wegierskiego w Polsce, w: Złota era kina wegierskiego..., s. 113.

${ }_{54}$ M. Mészáros, Ja, Marta..., Warszawa 1998, s. 52-53.

55 Jerzy Kochanowski słusznie zauważa, że rzadko podejmują się badacze analizy ważnego problemu zewnętrznych niezależnych kontaktów środowisk artystycznych w okresie zimnej wojny. Zob. 
sztuki zauważył, że dla twórców węgierskich kontakty z Polakami miały w owym czasie „znaczenie niemal egzystencjalne” 56 . Artyści mogli podróżować i nawiązywać nieoficjalne relacje dzięki ułatwieniom w ruchu turystycznym wewnątrz bloku ${ }^{57}$. Od początku lat sześćdziesiątych w przekazywaniu wartości inspirujących twórczość węgierskich filmowców pośredniczyło „pokolenie autostopowiczów” ${ }^{58}$. Jak stwierdził historyk Károly Kapronczay: „Wielu Węgrów jeździło do Polski właśnie dla filmów, które tam mogli obejrzeć”59.

Wracając do filmu Po drodze z Delphine Seyrig i Janem Nowickim w rolach głównych, wyprodukowanego wspólnie przez MAFILM Dialog Filmstudio (Budapeszt) oraz Zespół Filmowy „X”, stał się on przedmiotem rozmów prowadzonych przez wiceministra kultury i sztuki Wiesława Beka na Węgrzech pod koniec kwietnia 1979 r. Uznano go wówczas za „pozytywny objaw rozwoju współpracy filmowej"60. Ponadto PRL i Węgry były jednymi z koproducentów (wraz z Czechosłowacją, Bułgarią, Rumunią i NRD) propagandowego filmu radzieckiego pt. Żołnierze wolności $(1977)^{61}$.

Niektórych zamierzeń koprodukcyjnych z różnych przyczyn (trudno przesądzić, czy z powodu trudności scenariuszowych, realizacyjnych, czy cenzuralnych) nie udało się w omawianym czasie urzeczywistnić. Nie powstał polsko-węgierski film Miklósa Jancsó o gen. Józefie Bemie, choć w 1972 r. dyrektor Biura Organizacyjnego NZK Walerian Spychała na łamach „Trybuny Ludu” informował: „Wybitny węgierski reżyser Miklós Jancsó przy współpracy zespołu [„X”przyp. J.S.] reż. A. Wajdy nakręci film o gen. Bemie. Ta współprodukcja zapowiada się obiecująco, a film ma być zrealizowany w możliwie krótkim czasie (być może jeszcze w br.)"62. Współprodukcją z Polakami interesował się w omawianym

idem, Wstęp, w: Bocznymi drogami. Nieoficjalne kontakty społeczeństw socjalistycznych 1956-1989, red. W. Borodziej, J. Kochanowski, Warszawa 2010, s. 11.

56 J. Brendel, Polskie kontakty węgierskiej neoawangardowej sztuki plastycznej w późnym okresie „socrealizmu”, w: Polskie lato, wegierska jesień..., s. 88.

57 Szerzej na ten temat w kontekście współpracy z Polakami wykluczonymi z oficjalnego życia artystycznego plastyków z Węgier, Czechosłowacji i NRD piszą P. Wasiak i A. Witerska w artykule pt. Przestrzeń swobody. Wystawy „zakazanych” artystów z krajów socjalistycznych w Polsce po 1956 roku, w: Bocznymi drogami...

58 C. Kiss Gy., op. cit., s. 26-29. O odkrywaniu przez Węgrów w Polsce w latach siedemdziesiątych nieznanego im wcześniej stylu życia przepełnionego „duchem wolności” pisze też Judit Reiman. Zob. eadem, op. cit., s. 66-67.

${ }^{59} \mathrm{~K}$. Kapronczay, Historiografia kontaktów wegiersko-polskich w latach sześćdziesiątych i siedemdziesiątych, w: Polskie lato, węgierska jesień..., s. 53-54.

60 AAN, Komitet Centralny Polskiej Zjednoczonej Partii Robotniczej, sygn. LVI-739, Notatka problemowa z rozmów przeprowadzonych w czasie pobytu na Węgrzech na zaproszenie Sekretarza Stanu w Ministerstwie Kultury WRL, Ferenca Molarna w dniach 23-26.04.1979. Cyt. za: J. Szczutkowska, Polityka kulturalna PRL..., s. 307.

${ }^{61}$ Szerzej na temat filmu i jego genezy pisze M. Wojtczak, op. cit., s. 133-138.

62 J. Jurczyński, Bogate doświadczenia, „Trybuna Ludu” 22.04.1972, s. 4. O tym, że Miklós Jancsó przystępuje do realizacji filmu Józef Bem produkcji węgiersko-polskiej informowano też 
czasie także inny znany węgierski reżyser, András Kovács: „mamy scenariusz, który możemy zrobić w koprodukcji z Węgrami, zainteresował się nim Kovacs pt. Węgrzy - mówił Jerzy Kawalerowicz, referując zamierzenia produkcyjne i scenariuszowe zespołu „Tor” na 1975 r. w czasie narady u ministra Wojtczaka. - [...] Jest to temat dość dramatyczny, a ponieważ Kovács zrobił kilka takich filmów, ponieważ ten temat go interesuje, więc teraz zbiera materiały, będzie nam chciał we wrześniu przedstawić gotowy scenariusz, a wtedy będziemy mogli mówić o przystąpieniu do koprodukcji z Węgrami i jest to zupełnie możliwe"63.

Jak wynika z powyższych informacji, polsko-węgierskie osiągnięcia w zakresie wspólnych produkcji filmowych były w latach siedemdziesiątych relatywnie (w porównaniu z ZSRR) niewielkie. Powstały cztery koproducenckie dzieła dla kina i telewizji, $\mathrm{z}$ których połowa to efekt szerszego porozumienia kinematografii socjalistycznych. Dwóch wielkich projektów filmowych nie zrealizowano. Adam Horoszczak, oceniając historię polsko-węgierskich koprodukcji do pierwszej połowy lat dziewięćdziesiątych stwierdził:

\begin{abstract}
Niestety; poza wątkiem galicyjsko-podhalańskim w przypomnianych ostatnio przez TVP 80 huzarach Sándora Sáry; poza polsko-węgierskimi Dezerterami Janusza Majewskiego oraz marginaliami typu Po drodze Márty Mészáros albo Podróżny na gapę Sándora Sötha (nie wspominając polskiego serialu TV Trzecia granica) - do ambitniejszej i szerszej współpracy naszych kinematografii jak dotąd nie doszło. Choć mówiono od lat, że i Miklós Jancsó, i Andrzej Wajda, i András Kovács, rozważali projekty wspólnych polsko-węgierskich realizacji opartych na faktach Historii ${ }^{64}$.
\end{abstract}

Nie wszystkie plany udało się ziścić, jednakże z punktu widzenia dnia dzisiejszego samo już programowanie wspólnego przedsięwzięcia przez Wajdę i Jancsó można uznać za historyczne i symboliczne osiągnięcie. Sam Andrzej Wajda, który pozostawił kilkaset niezrealizowanych pomysłów, podsumowałby zapewne te rozważania stwierdzeniem: „marzenia są piękniejsze”65.

Jeśli chodzi o inne formy polsko-węgierskiej kooperacji filmowej w latach siedemdziesiątych, polegały one, podobnie jak w przypadku współpracy z innymi

W specjalistycznej prasie filmowej. Zob. np. L. Armatys, Filmy Miklósa Jancsó, „Kino” 1973, nr 3, s. 40. Współpraca z wybitnymi reżyserami z krajów socjalistycznych była ważnym punktem (który niestety „zupełnie nie wypalił”) programu Andrzeja Wajdy, przedstawionego na pierwszej konferencji prasowej Zespołu Filmowego „X”, którym kierował od 18 grudnia 1971 r. (w tym dniu Wajda otrzymał oficjalną nominację na kierownika artystycznego „Iksa”), T. Lubelski, Wajda. Portret mistrza w kilku odsłonach, Wrocław 2006, s. 134-136; A. Szczepańska, Do granic negocjacji. Historia Zespołu Filmowego „X” Andrzeja Wajdy (1972-1983), Kraków 2017, s. 96.

63 AAN, NZK, sygn. 1/65, Stenogram z narady Zespołów Filmowych, odbytej w dn. 5.03.1975 r. u ministra Wojtczaka na temat zamierzeń produkcyjnych i scenariuszowych Zespołów Filmowych na rok 1975. Cyt. za: J. Szczutkowska, Polityka kulturalna PRL..., s. 307.

64 A. Horoszczak, Polak, Węgier... i kino. Nasi u bratanków, „Iluzjon. Kwartalnik Filmowy” 1994, nr 2, s. 35.

65 A. Wajda, op. cit., s. 240-256. 
krajami socjalistycznymi, przede wszystkim na wzajemnym świadczeniu tzw. usług techniczno-produkcyjnych i inscenizacyjnych. Nie przynosiły one takich korzyści jak koprodukcje, ale miały niewątpliwy wpływ na rozwój produkcji filmowej obu krajów. Ich zakres obejmował m.in. angażowanie aktorów ${ }^{66}$. Wydaje się, że „wspólny rynek aktorski” w pewien sposób nawet rekompensował kinematografii polskiej niedostatki koprodukcyjne, tym bardziej że rozwijał się wówczas dość jednokierunkowo, tzn. polscy artyści, na których „moda” zaczęła się w drugiej połowie lat sześćdziesiątych, byli chętniej przyjmowani do pracy na Węgrzech ${ }^{67}$. W kilku dramatach społecznych Márty Mészáros z lat siedemdziesiątych wystąpił Jan Nowicki. Filmy te, zauważone przez węgierską krytykę, przyniosły aktorowi (notabene związanemu z Mészáros w życiu prywatnym) sławę na Węgrzech ${ }^{68}$. W tamtejszych produkcjach pojawiły się także Pola Raksa, Anna Nehrebecka, Anna Dymna, Magda Teresa Wójcik oraz Ewa Wiśniewska. Współpracą ze słynnym węgierskim reżyserem Miklósem Jancsó może pochwalić się Daniel Olbrychski, który znalazł się w obsadzie Agnus Dei (tytuł oryginalny Égi bárány), węgierskiego filmu Jancsó z 1971 r. (kolejny raz spotkali się na planie włoskiego telewizyjnego filmu fabularnego Rzym pragnie nowego cesarza z 1974 r. $)^{69}$. Jak podaje György Báron, Olbrychski nie był początkowo brany pod uwagę przy kompletowaniu obsady Agnus Dei. Reżyser zaproponował mu pamiętną rolę skrzypka po przypadkowym spotkaniu nad Balatonem ${ }^{70}$. Szczegółowy wykaz ról Polaków w węgierskich filmach z lat 1971-1980 prezentuje tabela 2. Choć, jak podkreśla Adam Horoszczak, „«złoty wiek» polskiego aktorstwa w madziarskim kinie” przyniosą dopiero lata osiemdziesiąte ${ }^{71}$, już w tzw. dekadzie gierkowskiej dano naszym aktorom szanse zaistnienia na tamtejszym rynku. Jak dotychczas udało się ustalić, ogółem w okresie tym polscy aktorzy wystąpili w 19 zróżnicowanych gatunkowo filmach fabularnych kinowych i telewizyjnych, nakręconych przez kilkunastu reżyserów, wśród których znaleźli się tacy twórcy światowej sławy, jak Miklós Jancsó czy István Szabó.

Poza wymianą aktorów, zakres wzajemnie świadczonych usług filmowych obejmował tak proste działania, jak wypożyczanie rekwizytów, kostiumów czy broni ${ }^{72}$, a ponadto realizację zdjęć, obsługę techniczną i produkcyjną. Węgrzy zaangażowali się $\mathrm{w}$ proces powstawania takich polskich filmów, jak np. sensacyjno-przygodowy Sto koni do stu brzegów (1978) Zbigniewa Kuźmińskiego (plenery, obsada aktorska,

${ }^{66}$ E. Zajiček, Film polski..., s. 96-97.

67 A. Horoszczak, Polak, Wegier..., s. 37.

68 Z. Szczygielska, Nowicki, Warszawa 1984, s. 63.

69 T. Kopyś, op. cit., s. 265.

70 G. Báron, Cisza i krzyk (Csend és kiáltás). Twórczość Miklósa Jancsó w latach 60. i 70., w: Złota era kina węgierskiego..., s. 52-53.

71 A. Horoszczak, Polak, Wegier..., s. 37.

72 AMSZ, DPWKN 13/83, Węgry 1978, Sprawozdanie z realizacji zaleceń dot. współpracy między PRL i WRL w dziedzinie kinematografii... 
Tabela 2. Polscy aktorzy w węgierskich filmach 1971-1980

\begin{tabular}{|c|c|c|c|c|}
\hline Lp. & $\begin{array}{c}\text { Rok } \\
\text { Premiery }\end{array}$ & $\begin{array}{l}\text { Tytuł filmu } \\
\text { (tytuł polski) }\end{array}$ & Reżyser & $\begin{array}{l}\text { Polscy } \\
\text { aktorzy }\end{array}$ \\
\hline 1. & 1971 & $\begin{array}{l}\text { Agnus Dei } \\
\text { (Baranek Boży) }\end{array}$ & $\begin{array}{l}\text { Miklós } \\
\text { Jancsó }\end{array}$ & Daniel Olbrychski (skrzypek) \\
\hline 2. & 1971 & $\begin{array}{l}\text { A gyilkos a házban van } \\
\text { (Morderca jest } w \text { domu) }\end{array}$ & Róbert Bán & Stanisław Mikulski (kapitan Tímár) \\
\hline 3. & 1973 & $\begin{array}{l}\text { Tüzoltó utca } 25 . \\
\text { (Ulica Strażacka 25) }\end{array}$ & $\begin{array}{l}\text { István } \\
\text { Szabó }\end{array}$ & Lucyna Winnicka (Maria) \\
\hline 4. & 1974 & Hószakadás (Śnieżyca) & Ferenc Kósa & Pola Raksa (polska spadochroniarka) \\
\hline 5. & 1975 & $\begin{array}{l}\text { Legenda a nyúlpapri- } \\
\text { kásról (Legenda o zaję- } \\
\text { czym paprykarzu) }\end{array}$ & $\begin{array}{l}\text { Barna } \\
\text { Kabay }\end{array}$ & $\begin{array}{l}\text { Wojciech Siemion } \\
\text { (wiejski „odmieniec”, Gazsi) }\end{array}$ \\
\hline 6. & 1975 & Várakozók (Oczekujące) & $\begin{array}{l}\text { Imre } \\
\text { Gyöngyössy }\end{array}$ & $\begin{array}{l}\text { Maja Komorowska (niania syna), } \\
\text { Jerzy Zelnik (dezerter - „syn”) }\end{array}$ \\
\hline 7. & 1975 & Oszlopos Simeon & \begin{tabular}{|l|} 
Károly \\
Esztergályos
\end{tabular} & Pola Raksa (Zsuzsi) \\
\hline 8. & 1976 & A járvány (Epidemia) & Pál Gábor & Anna Chodakowska (Anna) \\
\hline 9. & 1976 & $\begin{array}{l}\text { Kilenc hónap } \\
(\text { Dziewięć miesięcy })\end{array}$ & $\begin{array}{l}\text { Márta } \\
\text { Mészáros }\end{array}$ & Jan Nowicki (Bognár János) \\
\hline 10. & 1977 & $\begin{array}{l}\text { Budapesti mesék } \\
\text { (Budapeszteńskie } \\
\text { opowieści) }\end{array}$ & $\begin{array}{l}\text { István } \\
\text { Szabó }\end{array}$ & $\begin{array}{l}\text { Maja Komorowska, Franciszek Pieczka } \\
\text { (pasażerowie „tramwaju” Historii) }\end{array}$ \\
\hline 11. & 1977 & Kísértés (Pokusa) & $\begin{array}{l}\text { Károly } \\
\text { Esztergályos }\end{array}$ & Anna Nehrebecka (Kékine) \\
\hline 12. & 1977 & Ök ketten (One dwie) & $\begin{array}{l}\text { Márta } \\
\text { Mészáros }\end{array}$ & Jan Nowicki (János, mąż Julii) \\
\hline 13. & 1977 & Doktor Senki & $\begin{array}{l}\text { Levente } \\
\text { Málnay }\end{array}$ & $\begin{array}{l}\text { Małgorzata Braunek (Cziller Balázsné), } \\
\text { Małgorzata Krzewińska (Elza) }\end{array}$ \\
\hline 14. & 1978 & $\begin{array}{l}\text { Olyan, mint otthon } \\
\text { (Jak to } w \text { domu) }\end{array}$ & $\begin{array}{l}\text { Márta } \\
\text { Mészáros }\end{array}$ & Jan Nowicki (Novák András) \\
\hline 15. & 1979 & 80 huszár (80 huzarów) & Sándor Sára & $\begin{array}{l}\text { Stefan Szmidt (kapitan Vyss), Piotr } \\
\text { Wysocki (ksiądz), Grażyna Szapołowska } \\
\text { (Pola), Alicja Jachiewicz (dama), Henryk } \\
\text { Bista (chłop), Tatiana Sosna-Sarno oraz } \\
11 \text { polskich aktorów i „naturszczyków” } \\
\text { w scenach masowych }\end{array}$ \\
\hline 16. & 1979 & Útközben (Po drodze) & $\begin{array}{l}\text { Márta } \\
\text { Mészáros }\end{array}$ & $\begin{array}{l}\text { Beata Tyszkiewicz (Teresa), Jan Nowicki } \\
\text { (Marek), Halina Winiarska (Magda), } \\
\text { Jerzy Radziwiłłowicz (Színész) oraz } \\
\text { zespół „Piwnicy pod Baranami” }\end{array}$ \\
\hline 17. & 1979 & $\begin{array}{l}\text { Magyar rapszódia } \\
\text { (Węgierska rapsodia) }\end{array}$ & $\begin{array}{l}\text { Miklós } \\
\text { Jancsó }\end{array}$ & Anna Dymna (Hanna) \\
\hline
\end{tabular}




\begin{tabular}{|c|c|l|l|l|}
\hline Lp. & $\begin{array}{c}\text { Rok } \\
\text { Premiery }\end{array}$ & $\begin{array}{c}\text { Tytuł filmu } \\
\text { (tytuł polski) }\end{array}$ & \multicolumn{1}{|c|}{ Reżyser } & \multicolumn{1}{|c|}{$\begin{array}{c}\text { Polscy } \\
\text { aktorzy }\end{array}$} \\
\hline 18. & 1979 & Bolondok kvártélya & $\begin{array}{l}\text { Gergely } \\
\text { Horváth }\end{array}$ & $\begin{array}{l}\text { Ewa Wiśniewska (Zsófia), Magda Teresa } \\
\text { Wójcik (Eleonora) }\end{array}$ \\
\hline 19. & 1980 & $\begin{array}{l}\text { Örökség } \\
\left.\text { (Spadkobierczyni }^{73}\right)\end{array}$ & $\begin{array}{l}\text { Márta } \\
\text { Mészáros }\end{array}$ & $\begin{array}{l}\text { Jan Nowicki (Ákos), Piotr Skrzynecki } \\
\text { (wujek Fülöp) }\end{array}$ \\
\hline
\end{tabular}

Źródło: A. Horoszczak, Polscy aktorzy w wegierskich filmach powojennych (od roku 1945), „Iluzjon. Kwartalnik Filmowy” 1994, nr 2, s. 70-71; T. Kopyś, Stosunki polsko-weggierskie w latach 1945-1970, s. 265; www.imdb.com; www.filmweb.pl oraz www.filmpolski.pl.

współpraca produkcyjna) oraz historyczna superprodukcja Polonia Restituta (1980) Bohdana Poręby ${ }^{74}$. Polskich filmowców i specjalistów zaproszono natomiast do prac nad węgierskim filmem historycznym pt. 80 huzarów (1978). Reżyser Sándor Sára współpracował wówczas m.in. ze Zbigniewem Lewickim (II reżyser), Jerzym Braszką (współpraca reżyserska), znawcą militariów Jerzym Szeskim, Lechem Adamowskim (ewolucje kaskaderskie) oraz aktorami: Henrykiem Bistą, Andrzejem Buszewiczem, Grażyną Szapołowską. Ze strony polskiej funkcję kierownika produkcji pełnił Wilhelm Hollender ${ }^{75}$.

Duże znaczenie poznawcze i praktyczne miały bezpośrednie kontakty polskich i węgierskich filmowców. Dzięki porozumieniu pomiędzy SFP i Stowarzyszeniem Filmowców Węgierskich (SFW), ich przedstawiciele uczestniczyli m.in. w Międzynarodowym Festiwalu Filmów Krótkometrażowych w Krakowie, Międzynarodowym Festiwalu Filmów Fabularnych w Gdańsku oraz w odbywających się na Węgrzech: sympozjum operatorów, Kongresie Filmu Naukowego oraz Międzynarodowej Naradzie Przewodniczących Kinematografii i Stowarzyszeń Filmowców (prezes SFP $)^{76}$. W 1971 r. na zaproszenie SFP przebywała w Warszawie grupa realizatorów ze Studia im. Béli Balázsa (Budapeszt) ${ }^{77}$.

Realizacji współpracy filmowej służyła organizacja uroczystych premier, przeglądów, a także tzw. dni filmu i tygodni filmu oraz uczestnictwo w festiwalach. Dla przykładu, w dniach od 18 do 25 września 1974 r. odbywały się Dni Filmu Polskiego na Węgrzech. W tym samym roku zorganizowano, w ramach towarzyszących obchodom 30-lecia PRL Dni Kultury Polskiej, uroczystą węgierską premierę

\footnotetext{
${ }^{73} \mathrm{~W}$ polskiej literaturze tytuł filmu tłumaczony również jako: Spadek, zob. np. Z. Szczygielska, op. cit., s. 63.

74 AMSZ, DPWKN 13/83, Węgry 1978, Ocena stanu realizacji 5-letniego Planu Współpracy Kulturalnej... Dwuczęściowy film Polonia Restituta Bohdana Poręby miał swą premierę 18 maja 1981 r. Cieszył się wyjątkowymi „hollywoodzkimi” możliwościami realizatorskimi. Poza Węgrami, polskich twórców wspierali filmowcy z ZSRR, NRD i CSRS - szerzej na temat filmu zob. J. Eisler, Polonia Restituta, http://polska1918-89.pl/pdf/polonia-restituta-film,1841.pdf (dostęp: 13.04.2017).

75 J. Szczutkowska, Polityka kulturalna PRL..., s. 308.

76 AMSZ, DPWKN 13/83, Węgry 1978, Sprawozdanie z realizacji zaleceń dot. współpracy między PRL i WRL w dziedzinie kinematografii...

77 Kronika wydarzeń, „Filmowy Serwis Prasowy” 1971, nr 23, s. 2.
} 
filmu Ciemna rzeka Sylwestra Szyszki z udziałem reżysera ${ }^{78}$. Z kolei 3 kwietnia 1974 r. w warszawskim kinie „Skarpa” odbyła się premiera filmu Istvána Szabó pt. Ulica Strażacka 25 z udziałem delegacji filmowców węgierskich. Obecny był reżyser, aktorka Rita Békés oraz włączona do oficjalnej delegacji na życzenie strony węgierskiej Lucyna Winnicka, odtwórczyni roli Marii ${ }^{79}$. W 1975 r. odbył się Przegląd Filmów Polskich w Budapeszcie i Miszkolcu, w ramach którego zaprezentowano m.in. Faraona Jerzego Kawalerowicza, Lalkę Wojciecha Hasa i Jarzębinę czerwona Ewy i Czesława Petelskich a także, na życzenie widzów dwukrotnie powtarzany, specjalny przegląd twórczości Andrzeja Wajdy ${ }^{80}$. W tym samym roku w Warszawie i Katowicach zorganizowano Tydzień Filmu Węgierskiego. W 1976 r. odbył się Przegląd Nowych Filmów Węgierskich w Poznaniu ${ }^{81}$.

Nie zawsze współpraca przebiegała zgodnie z oczekiwaniami strony polskiej. W 1977 r., wbrew porozumieniom, nie odbyła się uroczysta premiera polskiego filmu; nie zorganizowano też Dni Filmu Polskiego ${ }^{82}$. Jednak już w roku następnym, zgodnie z planem, przygotowano w październiku uroczystą premierę Barw ochronnych $\mathrm{z}$ udziałem reżysera Krzysztofa Zanussiego. Ponadto w dniach od 22 lutego do 1 marca 1978 r. odbył się w Segedynie Tydzień Filmu Polskiego ${ }^{83}$. Obchody 35-lecia PRL Budapeszcie uświetnił uroczysty pokaz premierowy filmu Janusza Zaorskiego pt. Pokój z widokiem na morze ${ }^{84}$.

Do popularyzacji twórczości obu krajów przyczyniały się festiwale filmowe, nazywane czasem (bez względu na rangę i formułę) świętem kinematografii ${ }^{85}$. Filmy polskie prezentowano na międzynarodowych specjalistycznych festiwalach organizowanych w Budapeszcie: Międzynarodowym Festiwalu Filmów Sportowych, Międzynarodowym Festiwalu Filmów Technicznych, Międzynarodowym Festiwalu Filmów Przyrodniczych, a także w Veszprém: Międzynarodowym Festiwalu Filmów Instruktażowych i Międzynarodowym Festiwalu Filmów Wojskowych Armii Zaprzyjaźnionych. W 1973 r. na MFF Technicznych polscy filmowcy zdobyli dwa

78 AMSZ, DPWKN 13/83, Węgry 1978, Sprawozdanie z realizacji zaleceń dot. współpracy między PRL i WRL w dziedzinie kinematografii...; ibidem, Uwagi o polsko-węgierskiej współpracy naukowej i kulturalnej w $1974 \mathrm{r}$.

79 AMSZ, DPWKN 13/83, Węgry 1978, Sprawozdanie z realizacji zaleceń dot. współpracy między PRL i WRL w dziedzinie kinematografii...; ibidem, Uwagi o polsko-węgierskiej współpracy naukowej i kulturalnej w $1974 \mathrm{r}$.

80 B. Płaza, op. cit., s. 129-130.

${ }^{81}$ Ibidem, s. 130.

82 AMSZ, DPWKN 13/83, Węgry 1978, Uwagi o polsko-węgierskiej współpracy kulturalnej i naukowej w $1977 \mathrm{r}$.

83 AMSZ, DPWKN 13/83, Węgry 1978, Uwagi o współpracy kulturalnej i naukowej między PRL i WRL w $1978 \mathrm{r}$.

${ }^{84}$ AMSZ, DPWKN 13/83, Węgry 1978, Ocena stanu realizacji 5-letniego Planu Współpracy Kulturalnej...

85 Por. np. P. Pająk, Festiwal w Puli-poczatek i koniec filmowego święta w socjalistycznej Jugosławii, „Kwartalnik Filmowy” 2017, nr 100, s. 6. 
wyróżnienia w kategorii filmów oświatowych: II nagrodę otrzymał wówczas Anatol Fidek za film Luminescencja, zaś III nagrodę Józef Arkusz za film Elektronika tranzystorowa. W 1977 r. podczas MFF Sportowych nagrodą Węgierskiego Instytutu Kultury Fizycznej uhonorowano Jadwigę Żukowską, autorkę filmu Slalom. W roku następnym Grand Prix MFF Armii Zaprzyjaźnionych w Veszprém w kategorii filmów oświatowo-szkoleniowych otrzymał dokument Kazimierza Sheybala pt. Strach jest najgorszym doradcą. W 1978 r. w Veszprém wyróżniono także Edmunda Z. Szaniawskiego za dokument Dąbrowszczacy, któremu przyznano Nagrodę Specjalną KW Węgierskiej Socjalistycznej Partii Robotniczej Veszprém ${ }^{86}$. Z kolei filmowców z Węgier, np. reżysera Gábora Vitéza, zapraszano do udziału w takich polskich festiwalach i przeglądach, jak: Ogólnopolskie Sympozjum i Festiwal Filmów Dydaktycznych oraz Zagłębiowski Przegląd Filmów Amatorskich w Dąbrowie Górniczej ${ }^{87}$. W 1980 r. „Wielkim Jantarem” 8. Koszalińskich Spotkań Filmowych „Młodzi i Film” wyróżniono film Vera Angi (1979) Pála Gábora ${ }^{88}$. Oprócz tego, węgierskie filmy prezentowano na dorocznym przeglądzie światowego kina „Konfrontacje”. Przede wszystkim jednak kinematografia Węgier była obecna na Międzynarodowym Festiwalu Filmów Krótkometrażowych w Krakowie, nierzadko z sukcesami. W 1975 r. nagrodę specjalną - Złotego Smoka otrzymał film pt. Kowale/Tüzikovácsok (reż. János Zsombolyai). Nagrodą główną - Srebrnym Smokiem wyróżniono następujące dzieła: Szanowny adresacie/Tisztelt Cím (reż. Lívia Gyarmathy), 1972; Szaleństwa fasolek/Babfilm (reż. Ottó Foky), 1976 oraz Animália IV - A Macska (reż. Tibor Hernádi), 1980. Nagrodą specjalistyczną - Brązowym Smokiem za zdjęcia uhonorowano w 1978 r. Koszmar/Lidérc (reż. Péter Gárdos). Ponadto dyplomy honorowe odebrali twórcy filmów: Pogromca/ Siker (reż. Gyula Macskássy, GyörgyVárnai ), 1972; Młynarz znad czarnej rzeki/ Molnár a Cserna-Rékán (reż. Vince Lakatos), 1974; Bardzo lubię życie/Nekem az élet teccik nagyon (reż. Katalin Macskássy), 1977; Ketrec (reż. Péter Gárdos), $1980^{89}$.

W promowaniu dorobku „bratnich” krajów specjalizowały się Ośrodki Informacji i Kultury ${ }^{90}$. Do popularyzacji kinematografii polskiej na Węgrzech przyczyniła się działalność Ośrodka Informacji i Kultury Polskiej (OIKP) w Budapeszcie. Z kolei w Polsce realizacji tych celów służył Węgierski Instytut Kultury w Warszawie. Dzięki pracy tych placówek, wspieranych zgodnie z postanowieniami konwencji z 1948 r., rozpowszechniano kulturalne dziedzictwo obu narodów, starając się jak pisała w latach siedemdziesiątych Eugenia Podbierowa - wzbogacać tradycyjnie

${ }^{86}$ M. Hendrykowska, Kronika kinematografii polskiej 1895-1997, Poznań 1999, s. 520, 351, 359; „Filmowy Serwis Prasowy” 1971, nr 18, s. 2; „Filmowy Serwis Prasowy” 1980, nr 10, s. 21.

87 J. Szczutkowska, Polityka kulturalna PRL..., s. 69, 251, 310.

88 Od 1973 do 2007 r. jako Koszaliński Festiwal Debiutów Filmowych „Młodzi i Film” http://www. mlodziifilm.pl (dostęp: 08.04.2017).

89 http://www.krakowfilmfestival.pl/archiwum/nagrody-2016/ (dostęp: 13.02.2017).

90 Ocena stosunków PRL z krajami socjalistycznymi Europy w 1978 r. (będącymi w kompetencji Departamentu I), w: Polskie dokumenty dyplomatyczne 1979..., s. 37. 
bogate związki „o nową socjalistyczną treść" ${ }^{1}$. W tym ostatnim kontekście trudno stwierdzić, na ile udało się zrealizować założenia ówczesnych ideologów, tym bardziej że np. historyk István Rév zapamiętał OIKP jako „jedną z najważniejszych instytucji w Budapeszcie, która kreowała kulturę alternatywną i reprezentowała formułującą się w opozycji do oficjalnych nurtów neoawangardę"92.

Jeśli chodzi o działalność OIKP w sferze popularyzacji polskiego kina, dużym zainteresowaniem cieszyły się zwłaszcza Tygodnie Filmu Polskiego. Z kolei frekwencja na cotygodniowych projekcjach filmów fabularnych i dokumentalnych wahała się, osiągając nawet do 100 osób; najchętniej oglądano filmy Andrzeja Wajdy, Krzysztofa Zanussiego i Jerzego Kawalerowicza. W OIKP organizowano także specjalne pokazy najnowszych polskich filmów dla studentów polonistyki Uniwersytetu Budapeszteńskiego, absolwentów wyższych uczelni w Polsce i tłumaczy literatury. Również spotkaniom specjalistycznym towarzyszyły projekcje filmów, np. marynistycznych, tak jak to miało miejsce w 1977 r., kiedy w efekcie współdziałania z attaché ds. gospodarki morskiej odbył się pokaz z okazji Dni Morza. Projekcję trzech filmów: Port Północny, Promem przez Bałtyk i o promie Mikołaj Kopernik poprzedziła prelekcja na temat polskich portów morskich. Ośrodek zaopatrywał w polskie filmy domy kultury, kluby oraz zakłady pracy ${ }^{93}$.

Okazją do upowszechniania artystycznych osiągnięć były tzw. Tygodnie Przyjaźni Polsko-Węgierskiej, w których inauguracji uczestniczył ambasador Stefan Jędrychowski, a także przedstawiciele węgierskich władz politycznych, społecznych i administracyjnych. W $1977 \mathrm{r}$. odbyły się cztery tego typu imprezy, zorganizowane przez OIKP w komitatach: Bács-Kiskun, Baranya, Borsod-Abaúj-Zemplén oraz Heves. W ich programie znalazły się Tygodnie Filmu Polskiego ${ }^{94}$. W kolejnym roku wicedyrektor ośrodka Stanisław Zientak dokonał otwarcia Tygodnia Filmu Polskiego w komitacie Zala ${ }^{95}$. OIKP organizował Tygodnie Przyjaźni Polsko-Węgierskiej również w komitacie Nógrád (wspólnie z Komitetem Wojewódzkim Patriotycznego Frontu Ludowego). Także tam politycznym wydarzeniom towarzyszyły projekcje filmowe i spotkania literackie, podczas których fragmenty literatury polskiej recytował

${ }^{91}$ DzU 1948, nr 51, poz. 399, http://dokumenty.rcl.gov.pl/DU/rok/1948/wydanie/51/pozycja/399 (dostęp: 18.01.2016); E. Podbierowa, op. cit., s. 123. W 2014 r. swoje 75-lecie świętował Instytut Polski w Budapeszcie, oficjalnie otwarty 24 maja 1939 r. 19 marca 1944 r. Instytut został przymusowo zamknięty. Działalność wznowił siedem lat później, 15 marca 1951 r. pod nazwą Czytelnia Polska. Przez trzydzieści lat jako OIKP popularyzował kulturę polską z siedzibą przy Nagymező utca 15. 24 maja 1994 r. powrócono do nazwy Instytut Polski. Szerzej: 75 lat Instytutu Polskiego w Budapeszcie, Budapeszt 2014, http://issuu.com/lengyelintezetbudapest/docs/75ip_internet (dostęp: 08.04.2017) oraz strona internetowa Instytutu Polskiego w Budapeszcie: http://polinst.hu/pl.

9275 lat Instytutu Polskiego w Budapeszcie..., s. 67.

93 AMSZ, DPWKN 13/83, Węgry 1978, Sprawozdanie z działalności Ośrodka Informacji i Kultury w Budapeszcie w roku 1977.

94 Ibidem.

95 AMSZ, DPWKN 13/83, Węgry 1978, Notatka z przebiegu Tygodnia Przyjaźni Węgiersko-Polskiej w województwie Zala. 
węgierski aktor teatralny Tibor Bodor (1921-2000), oraz wystawy fotodokumentacyjne ${ }^{96}$. Z różnych względów nie udało się niektórych zamierzeń urzeczywistnić. O bolączkach placówki informowało w swoich sprawozdaniach kierownictwo OIKP. W jednym z nich dyrektor Władysław Kobiałka odnotował: „Odczuwamy brak filmów na temat rozwoju kultury w Polsce, teatru, muzeów, prezentujących życie młodzieży oraz krajoznawcze w tym stroje ludowe" ${ }^{\text {"97 }}$. W 1977 r. nie zrealizowano zaplanowanego Tygodnia w komitacie Fejér. Z jego organizacji wycofali się Węgrzy.

Stanowisko takie było - czytamy w oficjalnym sprawozdaniu OIKP - prawdopodobnie rezultatem niezatwierdzenia samej koncepcji tygodnia imprez i ich programu przez władze polityczne województwa. Towarzysze z Patriotycznego Frontu Ludowego zaproponowali nam wprawdzie imprezy zastępcze, były one jednak o tak małym znaczeniu propagandowym, że OIKP ze względów prestiżowych nie uznał za właściwe ich organizowanie ${ }^{98}$.

W szerzeniu wiedzy o filmie węgierskim w Polsce istotną rolę odgrywał Węgierski Instytut Kultury w Warszawie. Pod auspicjami tej placówki systematycznie prezentowano wystawy poświęcone kinematografii i organizowano projekcje zarówno nowości filmowych, jak i dzieł starszych twórców. W styczniu $1980 \mathrm{r}$. pokazem filmu Korona śmierci Ferenca Kósy rozpoczęto ciekawą inicjatywę - cykl pod nazwą „Historia Węgier na ekranie" 99 . Instytut zajmował się ponadto nadzorowaniem wizyt reżyserów, takich jak András Kovács, Péter Bacsó czy Miklós Jancsó. W październiku 1971 r. z okazji pobytu w Polsce Kovácsa odbył się pokaz jego najnowszych filmów (m.in. Ściany, Sztafeta). Imprezę przygotowano we współpracy ze Stowarzyszeniem Filmowców Polskich ${ }^{100}$. Regularnie organizowano uroczyste premiery i pokazy z okazji węgierskich świąt państwowych i rozmaitych rocznic, np. upaństwowienia węgierskiej kinematografii ${ }^{101}$. W kwietniu $1972 \mathrm{r}$. z okazji święta narodowego Węgier miała miejsce w Warszawie uroczysta premiera filmu Horyzont Pála Gábora z udziałem reżysera oraz odtwórców głównych ról. W 1978 r. z obchodami tej uroczystości państwowej powiązano premierę dramatu historycznego pt. 80 huzarów. Z tej okazji do Polski przybyli m.in. wicedyrektor NZK Péter Karikás oraz reżyser filmu Sándor Sára ${ }^{102}$. W tym samym roku, 22 listopada, w Instytucie odbył się pokaz filmów dokumentalnych z okazji sześćdziesiątej rocznicy powstania Komunistycznej Partii Węgier ${ }^{103}$.

96 AMSZ, DPWKN 13/83, Węgry 1978, Notatka z Tygodnia Przyjaźni Węgiersko-Polskiej zorganizowanego $w$ województwie Nógrád w dniach 29.05-2.06.br.

97 AMSZ, DPWKN 13/83, Węgry 1978, Sprawozdanie z działalności Ośrodka Informacji i Kultury w Budapeszcie w roku 1977.

98 Ibidem.

99 Kronika, „Filmowy Serwis Prasowy” 1980, nr 3, s. 24.

100 Kronika wydarzeń, „Filmowy Serwis Prasowy” 1971, nr 22, s. 2.

101 Kronika, „Filmowy Serwis Prasowy” 1979, nr 6, s. 30.

102 J. Szczutkowska, Polityka kulturalna PRL..., s. 308.

103 Kronika, „Filmowy Serwis Prasowy” 1979, nr 1, s. 23. 
Działalność Instytutu tak wspomina Andrzej Werner, aktywny w latach siedemdziesiątych działacz filmowy i historyk kina:

Urzędnicy w Instytucie Węgierskim mieli za zadanie rozpowszechniać dobre kino węgierskie. Wybierali to, co miało szanse na powodzenie w Polsce oraz to, co zapewne odpowiadało ich gustom, a byli to ludzie zaznajomieni z polskimi realiami i posiadający dobry gust. Skoro te filmy powstawały, to trzeba było je pokazać i oni umieli je pokazać. [...] Instytut pokazywał filmy na otwartych, organizowanych własnymi siłami pokazach. $\mathrm{Na}$ przykład, w Warszawie, w siedzibie Instytutu na Marszałkowskiej, odbywały się projekcje przyciągające najważniejszych krytyków filmowych w Polsce i ludzi, których - z czasem w coraz większej liczbie - zapraszano z klubów filmowych. Niewielka salka projekcyjna Instytutu pękała w szwach na każdym filmie węgierskim ${ }^{104}$.

Jak ocenia znawca problematyki węgierskiej Jerzy Robert Nowak, udało się „Węgrom na Marszałkowskiej” zaprezentować w zasadzie wszystkie dzieła wybitnych i sławnych twórców madziarskiego kina ${ }^{105}$.

Z Węgierskim Instytutem Kultury często współpracowały dyskusyjne kluby filmowe. Te przedsięwzięcia przyczyniły się do upowszechnienia zwłaszcza tzw. filmów problemowych, dla których w szerokiej dystrybucji zabrakło miejsca. Jak podkreśla historyk i krytyk filmowy Pál Pap, filmy prezentowane w klubach odegrały znaczącą rolę w uwrażliwianiu widzów na „najistotniejsze sprawy” ${ }^{106}$. Do puli specjalnej DKF trafily m.in.: Sztafeta i Październikowa niedziela Andrása Kovácsa, Ożywcze wiatry i Elektra, moja miłość Miklósa Jancsó, Budapeszteńskie opowieści Istvána Szabó i inne. Film węgierski zajmował w tym czasie wyjątkową pozycję w ruchu klubowym. Filmowców z Węgier zapraszano do uczestnictwa w seminariach Polskiej Federacji DKF (dla przykładu, gościem XXI Seminarium PF DKF był reżyser György Szomjas ${ }^{107}$ ), ich twórczość spotykała się z dużym zainteresowaniem i sympatią polskiej widowni. Jerzy Robert Nowak, chcąc podkreślić rolę kultury w umacnianiu więzi obu narodów, strawestował znane przysłowie i stwierdził, że szabla zaczęła ustępować miejsca filmowi ${ }^{108}$. Fenomen ten można tłumaczyć, za cytowanym już badaczem Andrzejem Wernerem, nie tylko oryginalną formułą estetyczną filmów węgierskich, ale także tym, że dostarczały tematów do refleksji nad sytuacją krajów zmagających się z uciskiem komunistów ${ }^{109}$. Nie bez znaczenia okazał się również sposób podejścia do przeszłości. Na początku lat siedemdziesiątych Instytut Węgierski zwrócił się z pytaniem: „Za co cenimy film węgierski?” do polskich krytyków filmowych, m.in. Konrada Eberhardta. Zdaniem Eberhardta

\footnotetext{
104 „Często nawet plakatów nie było..., s. 114-116.

105 J.R. Nowak, Wegry bliskie..., s. 311.

106 P. Pap, op. cit., s. 349.

107 XXI Seminarium Polskiej Federacji Dyskusyjnych Klubów Filmowych Szklarska Poręba 1976, „Film na Świecie” 1977, nr 2, s. 94.

108 Zob. J.R. Nowak, Węgry bliskie..., s. 297.

109 „Często nawet plakatów nie było..., s. 114-115, 120.
} 
o sukcesie wśród polskiej publiczności zadecydował głęboki autentyzm i czytelność kina węgierskiego, podczas gdy polskie dzieła były dla Węgrów trudne w odbiorze: „My z filmów węgierskich dowiadujemy się bardzo dużo o genezie świadomości narodowej, o dzisiejszych aspiracjach Węgrów; dla nich nasze filmy są zapisem prawie nieczytelnym"110. W tym kontekście warto także przywołać uzasadnienie zawarte w materiale źródłowym - publikacji DKF „Kwant” z Warszawy, a więc klubu, którego działalność odegrała szczególnie duży wpływ na wzrost popularności kina „bratanków” w Polsce ${ }^{111}$. W opracowaniu z 1977 r. czytamy: „Dyskusje z twórcami węgierskimi należały do najciekawszych, ponieważ dotykały spraw istotnych, drażniących, bolesnych. Nowe kino węgierskie inspirowało do myślenia, prowokowało sprzeciwy, proponowało polemikę na płaszczyźnie poważnej, nierzadko pryncypialnej"112.

Zdaniem węgierskich filmoznawców, DKF „Kwant” zorganizował więcej spotkań z najwybitniejszymi przedstawicielami ich kina niż jakikolwiek klub filmowy na Węgrzech ${ }^{113}$. „Trzymając rękę na pulsie rozwoju tej interesującej kinematografii środkowoeuropejskiej"114, każdego roku słynny warszawski DKF przygotowywał kilka polskich prapremier, specjalne przeglądy oraz seminaria dedykowane węgierskim twórcom. Zorganizowano np. przedpremierowy pokaz Czasu teraźniejszego, połączony ze spotkaniem dyskusyjnym z udziałem reżysera Pétera Bacsó oraz scenarzysty Pétera Zimrego (1973), a także Dziewięciu miesięcy, w którym uczestniczyli reżyserka Márta Mészáros i aktor Jan Nowicki (1976) ${ }^{115}$. Ważnym wydarzeniem artystycznym było seminarium poświęcone twórczości Miklósa Jancsó, przygotowane we współpracy z Węgierskim Instytutem Kultury w 1972 r. W dniach od 13 do 17 listopada publiczność DKF „Kwant” miała możliwość obejrzenia niemal całego dorobku fabularnego tego reżysera. Projekcjom towarzyszyły wykłady naukowców oraz krytyków: Alicji Helman, Konrada Eberhardta i Andrzeja Wernera. Redaktor miesięcznika „Filmkultúra” i wiceprzewodnicząca Międzynarodowej Federacji Krytyków Filmowych FIPRESCI Yvette Bíró dokonała wówczas, zdaniem Adama Horoszczaka, „Odważnej, bo bardzo szczerej prezentacji rozmaitych zarzutów i pretensji zgłaszanych pod adresem twórcy przez węgierską krytykę"116. Sam Miklós Jancsó (ze współpracownikami) był obecny pod-

${ }^{110}$ K. Eberhardt, Autentyzm narodowy, „Kultura Filmowa” 1972, nr 5, s. 2-4. Stosunek Konrada Eberhardta do kina węgierskiego analizuje też Piotr Zwierzchowski, op. cit., s. 82-83.

111 DKF „Kwant” powstał w 1965 r. z inicjatywy studentów Politechniki Warszawskiej. Pierwszym prezesem klubu został Józef Pietrucha, następnie w latach 1967-1969 funkcję tę pełnił Zdzisław Ulatowski. Trzecim prezesem DKF „Kwant”, sprawującym kierownictwo w tzw. dekadzie gierkowskiej, był Andrzej Słowicki (do 1984 r.) - 50 lat DKF Kwant, http://www.akademiafilmowa. pl/o_akademii,1,81,1,DKF-Kwant.html (dostęp: 13.04.2017).

112 Cyt. za: J.R. Nowak, Węgry bliskie..., s. 310.

113 Ibidem.

11450 lat DKF Kwant...

115 Kronika, „Kultura Filmowa” 1973, nr 6, s. 99; J. Szczutkowska, Polityka kulturalna PRL..., s. 312.

116 A. Horoszczak, Jancsó egzorcyzmowany w „Kwancie”, „Kultura Filmowa” 1973, nr 2, s. 104. 
czas dwóch ostatnich dni seminarium ${ }^{117}$. Według wspomnień Jerzego R. Nowaka, podczas imprezy „sale «trzeszczały w szwach» od naporu publiczności”, a będący pod jej wrażeniem polscy krytycy filmowi uznali za "modelową" pod wieloma względami ${ }^{118}$. Z kolei Andrzej Werner określił po latach inicjatywę "Kwantu” jako „wielkie wydarzenie”119. Za podsumowanie kontaktów nawiązanych przez DKF „Kwant” z kinematografią Węgier do 1977 r. można uznać Ogólnopolskie Seminarium Filmowe pod nazwą "Nowe kino węgierskie - wczoraj i dziś” (24-29 kwietnia 1977). Jego program, poza projekcjami i spotkaniami z twórcami, obejmował referaty i dyskusje. Redaktor naczelny węgierskiego tygodnika filmowego „Filmvilág” Zoltán Hegedűs przeprowadził wykład dotyczący młodych twórców kina węgierskiego, zaś wieloletni pracownik polskiej placówki dyplomatycznej na Węgrzech Jerzy Robert Nowak mówił o historii w węgierskich filmach. Andrzej Werner i Adam Horoszczak wygłosili referaty zatytułowane: „Kino węgierskie: w poszukiwaniu wspólnego mianownika” oraz „Węgierskie kino pytań - dziś” ${ }^{120}$.

Choć największe zasługi w popularyzowaniu kina węgierskiego przypisuje się „Kwantowi”, należy odnotować, że węgierscy twórcy utrzymywali kontakty także z innymi DKF-ami, przejawiającymi, oceniając z dzisiejszej perspektywy, niezwykłą aktywność. Pokazy filmów węgierskich i seminaria odbywały się m.in. w warszawskich DKF-ach „Zygzakiem” i „Hybrydy” ${ }^{21}$. W lutym 1977 r. na zaproszenie pierwszego z nich przyjechał do Polski z promocją filmu Epidemia Pál Gábor. W spotkaniu, które odbyło się w Warszawskim Ośrodku Kultury, wzięli udział odtwórczyni głównej roli Anna Chodakowska oraz István Krasztel z Węgierskiego Instytutu Kultury ${ }^{122}$. Popularności kina węgierskiego w ówczesnym ruchu klubowym dowodzą też spostrzeżenia Zdzisława Biegańskiego zawarte w opracowaniu poświęconym DKF „Mozaika” w Bydgoszczy: „W 1974 r. podejmowaliśmy po raz pierwszy gości z Węgier: Pála Sándora, operatora Elmera Ragalyia i dyrektora Instytutu Węgierskiego w Warszawie - Pála Papa. Z tą placówką utrzymywano zresztą szczególnie bliskie kontakty, a filmy bratanków były dobrze przyjmowane przez bydgoską widownię. Zdobywały nawet miano najlepszego filmu sezonu"123.

Na zakończenie warto zauważyć, że nie bez wpływu na wzajemne filmowe fascynacje pozostawała działalność towarzystw przyjaźni polsko-węgierskiej, współpraca

117 Szerzej na temat seminarium poświęconemu twórczości Jancsó: ibidem, s. 100-105; Miklós Jancsó zwierza się warszawskiej publiczności, „Kino” 1973, nr 3. s. 41-43.

118 J.R. Nowak, Węgry bliskie..., s. 310.

119 „Często nawet plakatów nie było..., s. 114.

120 Informacja o Seminarium za: „Film na Świecie” 1977, nr 9, s. 92.

121 „Często nawet plakatów nie było..., s. 114.

122 „Film na Świecie” 1977, nr 6, s. 119.

123 Z. Biegański, Nieustający seans filmowy. 40 lat KMF „Mozaika” i DKF „Rondo” w Bydgoszczy, Bydgoszcz 1999, s. 24. 
władz lokalnych, a także półlegalnych środowisk autonomicznych. O ile jednak w Polsce towarzystwa przyjaźni polsko-węgierskiej mogły działać, w „gulaszowym komunizmie" wszelkie próby utworzenia tego typu organizacji ukrócano ${ }^{124}$. Do popularyzacji kina obu narodów przyczyniała się zwłaszcza aktywność Towarzystwa Przyjaciół Węgier w Tarnowie ${ }^{125}$ oraz Polskiego Stowarzyszenia Kulturalnego im. Józefa Bema na Węgrzech, założonego 9 maja 1958 r. i uhonorowanego przez Ministerstwo Kultury i Sztuki PRL odznaką „Zasłużony dla kultury polskiej”. Stowarzyszenie angażowało się w organizację rozmaitych imprez: wieczornic z okazji świąt państwowych PRL i WRL, wieczorów pieśni i tańca, spotkań z pisarzami i aktorami, koncertów, projekcji filmów, wystaw ${ }^{126}$. Wzajemnej propagandzie filmowej służyły wreszcie kontakty miast partnerskich, czego przykładem mogą być związki Lublina z Debreczynem ${ }^{127}$.

Podsumowując, wielowiekowe przyjazne kontakty Polaków i Węgrów oraz „dobry klimat polityczny” sprzyjały rozszerzeniu stosunków kulturalnych w latach siedemdziesiątych, do czego dążyły władze obu państw. Szczególnie ważną dziedziną, z perspektywy kontaktów oficjalnych, ale także prywatnych, okazały się film i kinematografia. Rezultaty władze polskie oceniały jako „pomyślne”. Jako satysfakcjonujący odbierano rozwój usług filmowych, współpracę filmotek, a nade wszystko fakt, że udało się zakupić i udostępnić widzom najważniejsze dzieła twórców filmowych z Polski i Węgier ${ }^{128}$. Również w pamięci zbiorowej lata siedemdziesiąte zapisały się pod tym względem w sposób szczególny. Oczywiście, nie wszystkie zamierzenia produkcyjne i pomysły popularyzatorskie udało się zrealizować. Jednak ze zgromadzonych danych wynika, że niedostatki koprodukcyjne wynagradzał w pewien sposób dość prężny „rynek aktorski”, panująca wśród Węgrów „moda na Polskę” oraz fenomenalna, trudna dzisiaj do powtórzenia, recepcja kina madziarskiego w ruchu klubowym i studyjnym. W efekcie, dzięki wielotorowym przedsięwzięciom i inicjatywom twórczym filmowców i miłośników sztuki filmowej, współpraca z omawianych lat stanowi jeden $\mathrm{z}$ ciekawszych rozdziałów w dziejach związków kinematografii dwóch bliskich sobie narodów.

124 Dopiero w 1987 r. zezwolono na powstanie towarzystwa przyjaźni w ramach Patriotycznego Frontu Ludowego, C. Kiss Gy., op. cit., s. 22-23, 29.

125 J.R. Nowak, Wegry bliskie..., s. 311.

126 R. Dzieszyński, Polak, Wegier... Millenium przyjaźni, Warszawa 1988, s. 81-82, 85-88.

127 Kronika wydarzeń, „Filmowy Serwis Prasowy” 1971, nr 14, s. 1; http://lublin.eu/lublin/wspolpraca-miedzynarodowa/miasta-partnerskie-i-zaprzyjaznione/debreczyn,9102,w.html (dostęp: 13.04.2017).

128 AMSZ, DPWKN 13/83, Węgry 1978, Ocena stanu realizacji 5-letniego Planu Współpracy Kulturalnej... 


\section{ANEKS}

Długometrażowe filmy węgierskie rozpowszechniane w kinach w Polsce w latach 1971-1980

\begin{tabular}{|c|c|c|}
\hline 1. & Adopcja (Örökbefogadás) & Márta Mészáros \\
\hline 2. & Budapeszteńskie opowieści (Budapesti mesék) KS i DKF & István Szabó \\
\hline 3. & Chwytajcie i bierzcie (Fogjuk meg és vigyétek) & Gábor Oláh \\
\hline 4. & Co się zdarzyło z profesorem (N.N. a halál angyala) & János Herskó \\
\hline 5. & Czarne diamenty (Fekete gyémántok) & Zoltán Várkonyi \\
\hline 6. & Czas teraźniejszy (Jelenidö) KS & Péter Bacsó \\
\hline 7. & Czyje to prawo? (Kinek a törvénye?) & Sándor G. Szönyi \\
\hline 8. & Diabeł bije żonę (Veri az ördög a feleségét) & Ferenc András \\
\hline 9. & Dom pod czerwoną latarnią (Egy erkölcsös éjszaka) & Károly Makk \\
\hline 10. & Dora nadaje (Dóra jelenti) & Róbert Bán \\
\hline 11. & Do siego roku (BUÉK!) & Rezsö Szörény \\
\hline 12. & Dziewczęta jak iskry (Szikrázó lányok) & Péter Bacsó \\
\hline 13. & Dziewczyna i auto (Autó) & Géza Böszörményi \\
\hline 14. & Dziewięć miesięcy (Kilenc hónap) & Márta Mészáros \\
\hline 15. & Elektra, moja miłość (Szerelmem, Elektra) KS i DKF & Miklós Jancsó \\
\hline 16. & Epidemia (A járvány) KS i DKF & Pál Gábor \\
\hline 17. & Film o miłości (Szerelmesfilm) & István Szabó \\
\hline 18. & Fortepian w powietrzu (Zongora a levegöben) & Péter Bacsó \\
\hline 19. & Gdzie jest jubilat? (Álljon meg a menet!) & Lívia Gyarmathy \\
\hline 20. & Gdzie pani jest, Déry? (Déryné, hol van?) KS i DKF & Gyula Maár \\
\hline 21. & Gęsiarek Maciek (Lúdas Matyi) & Attila Dargay \\
\hline 22. & Gospodarz stadniny (A ménesgazda) KS & András Kovács \\
\hline 23. & Granice miłości (A szerelem határai) & János Szücs \\
\hline 24. & Horyzont (Horizont) & Pál Gábor \\
\hline 25. & I zbaw nas od złego (Szabadíts meg a gonosztól) KS & Pál Sándor \\
\hline 26. & Jak to $w$ domu (Olyan, mint otthon) & Márta Mészáros \\
\hline 27. & Jesteśmy nadzy (Meztelen vagy) KS & Imre Gyöngyössy \\
\hline 28. & Kajtek i siedmiogłowy smok (Hahó, Öcsi!) & $\begin{array}{l}\text { György Palásthy, } \\
\text { Miklós Temesi }\end{array}$ \\
\hline 29. & Kangur (A Kenguru) & János Zsombolyai \\
\hline 30. & Kochana ciocia Sarika (Sárika, drágám) & Pál Sándor \\
\hline 31. & Korona śmierci (Ítélet) & Ferenc Kósa \\
\hline 32. & Księżniczka czardasza (Csárdáskirálynő) & Miklós Szinetár \\
\hline 33. & Legenda o zajęczym paprykarzu (Legenda a nyúlpaprikásról) KS i DKF & Barna Kabay \\
\hline 34. & Liliowa akacja (Lila ákác) & István Székely \\
\hline
\end{tabular}




\begin{tabular}{|c|c|c|}
\hline Lp. & Tytuł (tytuł oryginalny) & Reżyser \\
\hline 35. & Martwy pejzaż (Holt vidék) & István Gaál \\
\hline 36. & Marzenia miłosne (Szerelmi álmok - Liszt) & Márton Keleti \\
\hline 37. & Mężczyźni w krótkich spodenkach (Szépek és bolondok) & Péter Szász \\
\hline 38. & Miasto w czerni (A fekete város) & Éva Zsurzs \\
\hline 39. & Miecz (A kard) & János Dömölky \\
\hline 40. & Miłość (Szerelem) KS & Károly Makk \\
\hline 41. & Miły sąsiad (A kedves szomszéd) & Zsolt Kézdi-Kovács \\
\hline 42. & Modelka (Bübájosok) & János Rózsa \\
\hline 43. & Morderca jest $w$ domu (A gyilkos a házban van) & Róbert Bán \\
\hline 44. & Mrowisko (Hangyaboly) & Zoltán Fábri \\
\hline 45. & Na bialym koniu (Egy srác fehér lovon) & György Palásthy \\
\hline 46. & Na cichej stacyjce (Kihajolni veszélyes) & János Zsombolyai \\
\hline 47. & Najlepsze lata w życiu mężczyzny (A legszebb férfikor) & Sándor Simó \\
\hline 48. & Niczyje dziecko (Árvácska) KS i DKF & László Ranódy \\
\hline 49. & Nieposkromieni hajducy (Hajdúk) & Ferenc Kardos \\
\hline 50. & Oblicze $(A r c)$ & Pál Zolnay \\
\hline 51. & Ofiara (Az áldozat) & György Dobray \\
\hline 52. & One dwie (Ök ketten) & Márta Mészáros \\
\hline 53. & 80 huzarów (80 huszár) & Sándor Sára \\
\hline 54. & Ożywcze wiatry (Fényes szelek) DKF & Miklós Jancsó \\
\hline 55. & Październikowa niedziela (Októberi vasárnap) KS i DKF & András Kovács \\
\hline 56. & Piąta pieczęć (Az ötödik pecsét) & Zoltán Fábri \\
\hline 57. & Pod prąd (Kitörés) & Péter Bacsó \\
\hline 58. & Po drodze (Útközben) & Márta Mészáros \\
\hline 59. & Podróż dookoła mojego mózgu (Utazás a koponyám körül) KS & György Révész \\
\hline 60. & Podróże z Jakubem (Utazás Jakabbal) & Pál Gábor \\
\hline 61. & Polewaczka (A locsolókocsi) & Zsolt Kézdi-Kovács \\
\hline 62. & Porażenie prądem (Áramütés) & Péter Bacsó \\
\hline 63. & Poza czasem (Nincs idö) KS i DKF & Ferenc Kósa \\
\hline 64. & $\operatorname{Ring}($ K.O. $)$ & Tamás Rényi \\
\hline 65. & Romantyk (Romantika) & Zsolt Kézdi-Kovács \\
\hline 66. & Rycerz szklanego ekranu (Gyula vitéz télen-nyáron) & István Bácskai Lauro \\
\hline 67. & Sindbad (Szindbád) & Zoltán Huszárik \\
\hline 68. & Sirocco (Sirokkó) DKF & Miklós Jancsó \\
\hline 69. & Sokoły (Magasiskola) & István Gaál \\
\hline 70. & Sprawdzam siebie (Vállald önmagadat) & Frigyes Mamcserov \\
\hline
\end{tabular}




\begin{tabular}{|c|l|l|}
\hline Lp. & \multicolumn{1}{|c|}{ Tytul (tytul oryginalny) } & \multicolumn{1}{c|}{ Reżyser } \\
\hline 71. & Stary człowiek (Az öreg) KS i DKF & György Révész \\
\hline 72. & Swobodny oddech (Szabad lélegzet) & Márta Mészáros \\
\hline 73. & Sztafeta (Staféta) DKF & András Kovács \\
\hline 74. & Snieżyca (Hószakadás) & Ferenc Kósa \\
\hline 75. & Tajemniczy upiór (Kísértet Lublón) & Róbert Bán \\
\hline 76. & Trawnik wujka Poldi (Égigérö fü) & György Palásthy \\
\hline 77. & Tylko jeden telefon (Csak egy telefon) & Frigyes Mamcserov \\
\hline 78. & Udręka samotności (Teketória) KS i DKF & Gyula Maár \\
\hline 79. & U kresu (Végül) & Gyula Maár \\
\hline 80. & W cieniu legendy (Legato) & István Gaál \\
\hline 81. & Weegierska rapsodia (Magyar rapszódia) & Miklós Jancsó \\
\hline 82. & Weegrzy (Magyarok) & Zoltán Fábri \\
\hline 83. & Zabawa w koty (Macskajáték) KS i DKF & Károly Makk \\
\hline
\end{tabular}

Źródło: A. Horoszczak, A.M. Rutkowski, Film wegierski w Polsce, s. 289-292; „Filmowy Serwis Prasowy” 19711980; www.imdb.com; www.filmweb.pl.

\section{Cultural cooperation between Poland and Hungary in the field of filmmaking in the 1970s}

\section{Abstract}

The article presents in a synthetic way the course of Polish-Hungarian cooperation in the field of filmmaking in 1971-1980, with taking into account political and historical considerations. An analysis included, besides the scholarly literature on the subject, documents from the archives of the Ministry of Foreign Affairs in Warsaw. It was the area of film and filmmaking that made it possible for the Polish People's Republic and the Hungarian People's Republic to establish quickly cultural relations after World War Two. Traditionally strong friendship, strengthened by legal instruments of cultural cooperation, gave fertile grounds for the intensification of contacts in the 1970s. During the so-called Gierek's era, the Hungarian cinema enjoyed outstanding artistic success in Poland, while in Hungary at the same time Polish films were still "in vogue" since the last decade. The Polish-Hungarian cooperation in the field of filmmaking was legally framed by agreements signed by the Chief Boards of Cinema of the Polish Ministry of Culture and Arts and of the Hungarian Ministry of Culture for two years. The most important aspects of cooperation included: cooperation in filmmaking, exchange of services, official premieres with the participation of representatives of filmmakers, and various events, such as "days of" or "weeks of film", or retrospections - organised jointly, or by way of reciprocity, and the participation in film festivals. There were three works made in coproduction for cinema and television: a war drama Snowfall by Ferenc Kósa (1973), a TV series by Wojciech Solarz and Lech Lorentowicz under the title of The Third Frontier (1975), and a psychological film by Márta Mészáros On the Move (1979). In addition, Poland and Hungary coproduced (together with Czechoslovakia, Bulgaria, Romunia, and the German Democratic Republic) a propaganda Soviet film entitled Soldiers of Freedom (1977) by Yuri 
Ozerov. Two great film projects - by Miklós Jancsó and András Kovács - were not realised. A dynamically developing market of film services (especially an exchange of actors) provided certain compensation for coproduction shortages. As regards purchases and distribution of films, Hungarian films were showed in Poland, and Polish films in Hungary, but without broad distribution of so-called problem films. These were displayed in cameral studio cinemas and within film societies. At that time the Hungarian cinema occupied a special position in the film society movement and was met with great interest and sympathy of the Polish audience. An important part in the popularisation of mutual achievements was played by the Centre of Polish Information and Culture in Budapest and the Hungarian Institute of Culture in Warsaw, but also independent contacts of film lovers.

Translated by Grażyna Waluga

\section{Культурное сотрудничество Польши и Венгрии в области кинематографа в 70-х гг. ХХ века}

\section{Абстракт}

Статья синтетически представляет развитие польско-венгерского киносотрудничества в 1971-1980 гг., учитывая политико-исторические обстоятельства. Кроме доступной в научном обороте литературы предмета, анализировались материалы из фондов Архива Министерства иностранных дел в Варшаве.

Фильм и кинематограф являлись областью культуры и искусства, которая быстрее всего после Второй мировой войны соединила Польскую Народную Республику (ПНР) и Венгерскую Народную Республику (ВНР). Традиционные узы дружбы, укрепленные правовым инструментарием культурного сотрудничества, создали благоприятную почву для интенсификации контактов в этой области в 70-х гг. XX века. В т.н. декаде Герека мадьярский кинематограф добился в Польше своего исключительного артистического успеха, а в свою очередь в Венгрии продолжалась «мода» на польское кино, порожденная в предыдущей декаде. Кинематографическое сотрудничество ПНР-ВНР было определено прямыми соглашениями, заключаемыми на двухлетний период Главными Управлениями Кинематографа (ГУК) Министерства культуры и искусства ПНР и Министерства культуры ВНР. Наиболее важными проявлениями сотрудничества были: совместное производство картин, обмен услугами, торжественные премьерные показы с участием делегаций кинематографистов и мероприятия, такие как «дни» и «недели кино» или ретроспективные показы, которые организовались совместно и по принципу взаимности, а также участие в кинофестивалях. Были созданы три совместные ленты для кино и телевидения: военная драма Снегопад Ференца Коша (1973), многосерийный телевизионный фильм Войцеха Соляжа и Леха Лорентовича Третья граница (1975), психологическая картина Марты Месарош $B$ nути (1979). Кроме того, Польша и Венгрия были одними из производителей (совместно с Чехословакией, Болгарией, Румынией и Германской Демократической Республикой) пропагандистского советского фильма Солдать свободы (1977), реж. Юрия Озерова. Не были осуществлены два больших кинопроекта Миклоша Янчо и Андраша Ковача. Своего рода компенсацией дефицитов совместного производства являлся динамично развивающийся рынок киноуслуг (особенно обмен актерами). Что касается покупки и проката фильмов, то на экраны обеих стран попадало большинство лент, произведенных в ПНР и ВНР, но было отказано в широком прокате т.н. проблемным фильмам. Картины из этой группы были направлены в сети т.н. студийных кинотеатров, а также в дискуссионные киноклубы. Венгерский кинематограф 
в это время занимал в клубном движении исключительное положение, вызывая большой интерес и симпатию польской аудитории. Важную роль в популяризации взаимных достижений сыграли Центр информации и польской культуры в Будапеште и Венгерский институт культуры в Варшаве, а также независимые контакты кинолюбителей.

Перевод Агнешка Поспишиль

\section{Bibliografia}

\section{Źródła:}

Cultural policy in Hungary. A survey prepared under the auspices of the Hungarian National Commission for Unesco, Paris 1974.

Mészáros M., Ja, Marta..., Warszawa 1998.

Polskie dokumenty dyplomatyczne 1973, red. P. M. Majewski, Warszawa 2006.

Polskie dokumenty dyplomatyczne 1979, red. P. Długołęcki, J. Kochanowski, Warszawa 2014.

Tejchma J., Kulisy dymisji. Z dzienników ministra kultury 1974-1977, Kraków 1991.

Wajda A., Kino i reszta świata, Kraków 2000.

Wojtczak M., Kronika nie tylko filmowa, Warszawa 2004.

\section{Opracowania:}

Armata J., Wegierskie kino, w: Encyklopedia kina, red. T. Lubelski, Warszawa 2010.

„Często nawet plakatów nie było...” Rozmowa $z$ Andrzejem Wernerem o recepcji kina wegierskiego w Polsce, w: Złota era kina wegierskiego. Lata 60. i 70., red. R. Kardzis, J. Topolski, Kraków 2009.

75 lat Instytutu Polskiego w Budapeszcie, Budapeszt 2014, http://issuu.com/lengyelintezetbudapest/docs/75ip_internet.

Báron G., Cisza i krzyk (Csend és kiáltás). Twórczość Miklósa Jancsó w latach 60. i 70., w: Złota era kina wegierskiego. Lata 60. i 70., red. R. Kardzis, J. Topolski, Kraków 2009.

Báron G., Wprowadzenie do perspektywy lat 60., w: Złota era kina węgierskiego. Lata 60. i 70., red. R. Kardzis, J. Topolski, Kraków 2009.

Biegański Z., Kino puli specjalnej. Filmy jugosłowiańskie na ekranach kin Polski Ludowej, w: Polska i Jugosławia w stosunkach międzynarodowych po II wojnie światowej. Relacje wielostronne i wielopoziomowe, red. M. Pavlović, A. Zaćmiński, Bydgoszcz 2014.

Biegański Z., Nieustający seans filmowy. 40 lat KMF „Mozaika” i DKF „Rondo” w Bydgoszczy, Bydgoszcz 1999.

Brendel J., Polskie kontakty węgierskiej neoawangardowej sztuki plastycznej w późnym okresie „socrealizmu”, w: Polskie lato, węgierska jesień. Polsko-węgierska solidarność w latach 1956-1990, red. C. Kiss Gy., K. Sutarski, Budapeszt 1997.

Bubak G., Twórczość filmowa Istvána Szabó, Kraków 2003.

Bubak G., Miklós Jancsó. Obraz trudnej historii, w: Autorzy kina europejskiego VI, red. A. Helman, A. Pitrus, Warszawa 2011.

Cziomer E., Polityka odprężenia Wschód - Zachód w latach 70. i 80., w: Międzynarodowe stosunki polityczne, red. E. Cziomer, Kraków 2008.

Dabert D., Kino moralnego niepokoju. Wokół wybranych problemów poetyki i etyki, Poznań 2013.

Dzieszyński R., Polak, Wegier... Millenium przyjaźni, Warszawa 1988.

Eisler J., Polonia Restituta, http://polska1918-89.pl/pdf/polonia-restituta-film,1841.pdf. 
Engelmayer Á., Echo, pamięć i rola rewolucji wegierskiej 1956 r. w polskich publikacjach prasowych i książkowych drugiego obiegu (wydawanych nielegalnie) w latach siedemdziesiatych i osiemdziesiątych, w: Polskie lato, wegierska jesień. Polsko-wegierska solidarność w latach 1956-1990, red. C. Kiss Gy., K. Sutarski, Budapeszt 1997.

Felczak W., Fischinger A., Polska - Wegry, tysiąc lat przyjaźni, Budapeszt-Warszawa 1979.

Gołembski F., Współpraca kulturalna w procesie budowy europejskiego ładu pokojowego, Warszawa 1979.

Hendrykowska M., Kronika kinematografii polskiej 1895-1997, Poznań 1999.

Horoszczak A., Jancsó egzorcyzmowany w „Kwancie”, „Kultura Filmowa” 1973, nr 2, s. 100-105.

Horoszczak A., Polak, Węier... i kino. Nasi u bratanków, „Iluzjon. Kwartalnik Filmowy” 1994, nr 2, s. 35-42.

Horoszczak A., Polscy aktorzy w wegierskich filmach powojennych (od roku 1945), „Iluzjon. Kwartalnik Filmowy" 1994, nr 2, s. 70-74.

Horoszczak A., Rutkowski A.M., Film wegierski w Polsce, Warszawa 1981.

Jarząbek W., Polska wobec Konferencji Bezpieczeństwa $i$ Wspótpracy w Europie. Plany i rzeczywistość 1964-1975, Warszawa 2008.

Kaczor T., Przyjaźń z tysiącletnim rodowodem, w: Przyjaźń z tysiącletnim rodowodem. Szkice $z$ dziejów relacji polsko-węgierskich, red. P. Jakóbczyk-Adamczyk, D. Rogut, Bełchatów 2009.

Kapronczay K., Historiografia kontaktów wegiersko-polskich w latach sześćdziesiątych i siedemdziesiątych, w: Polskie lato, węgierska jesień. Polsko-węgierska solidarność w latach 19561990, red. C. Kiss Gy., K. Sutarski, Budapeszt 1997.

Kiss Gy. C., Pielęgnacja tradycji przyjaźni polsko-węgierskiej jako jedna z form opozycyjności (pytania i przybliżenia), w: Polskie lato, węgierska jesień. Polsko-węgierska solidarność w latach 1956-1990, red. C. Kiss Gy., K. Sutarski, Budapeszt 1997.

Kochanowski J., Wstęp, w: Bocznymi drogami. Nieoficjalne kontakty społeczeństw socjalistycznych 1956-1989, red. W. Borodziej, J. Kochanowski, Warszawa 2010.

Kopyś T., Stosunki polsko-węgierskie w latach 1945-1970, Kraków 2015.

Kossak J., Rozwój kultury w Polsce Ludowej, Warszawa 1974.

Lubelski T., Wajda. Portret mistrza w kilku odsłonach, Wrocław 2006.

Misiak A., Kinematograf kontrolowany. Cenzura filmowa $w$ kraju socjalistycznym i demokratycznym (PRL i USA). Analiza socjologiczna, Kraków 2006.

Nemeskürty I., Historia filmu węgierskiego, Warszawa 1979.

Nowak J.R., Polityka kulturalna WSPR w latach 1968-1977, Warszawa 1978.

Nowak J.R., Uparty rozrachunek, „Kino” 1981, nr 6, s. 31-32.

Nowak J.R., Węgry bliskie i nie znane, Warszawa 1980.

Pająk P., Festiwal w Puli - początek i koniec filmowego święta w socjalistycznej Jugosławii, „Kwartalnik Filmowy" 2017, nr 100, s. 6-21.

Pałyga E.J., Dyplomacja Polski Ludowej 1944-1984. Kierunki - treści - mechanizmy, Warszawa 1986.

Pap P., O wzajemnych kontaktach kinematografii polskiej i wegierskiej, w: Polska i Wegry w kulturze i cywilizacji europejskiej, red. J. Wyrozumski, Kraków 1997.

Płaza B., Kultura zbliża narody. O wspótpracy kulturalnej Polski z zagranica w latach 1945-1976, Warszawa 1978.

Podbierowa E., Stosunki między Polska a Węrami, w: Stosunki Polski z innymi państwami socjalistycznymi, red. Cz. Mojsiewicz, Warszawa 1973.

Polska i Niemcy. Filmowe granice i sasiedztwa, red. K. Klejsa, Wrocław 2012.

Polsko-włoskie kontakty filmowe. Topika, koprodukcje, recepcja, red. A. Miller-Klejsa, M. Woźniak, Łódź 2014.

Reiman J., Węgierskie postrzeganie Polaków w latach osiemdziesiątych, w: Narody i stereotypy, red. T. Walas, Kraków 1995. 
Sirecka-Wołodko M., Zagraniczna polityka kulturalna Polski w latach 1956-1970, Toruń 2011. Skobelski R., Polityka PRL wobec państw socjalistycznych w latach 1956-1970. Wspótpraca napięcia - konflikty, Poznań 2010.

Skopal P., Barrandov's co-productions. The Clumsy Way to Ideological Control, International Competitiveness and Technological Improvement, w: Cinema in Service of the State. Perspectives on Film Culture in the GDR and Czechoslovakia, 1945-1960, red. L. Karl, P. Skopal, New York - Oxford 2017.

Skrzypek A., Dyplomatyczne dzieje PRL w latach 1956-1989, Pułtusk-Warszawa 2010.

Studia z dziejów polsko-węgierskich stosunków literackich, red. István Csapláros, Warszawa 1978.

Studia $z$ dziejów polsko-węgierskich stosunków literackich i kulturalnych, red. J. Reychman, I. Csapláros, A. Sieroszewski, Wrocław 1969.

Szczepańska A., Do granic negocjacji. Historia Zespołu Filmowego „X” Andrzeja Wajdy (19721983), Kraków 2017.

Szczutkowska J., „Żywotność i znaczenie” - współpraca kulturalna Polski z Węrami w latach 70. XX wieku, w: Historia kluczem do zrozumienia współczesnych relacji międzysąsiedzkich, red. T. Maresz, K. Grysińska-Jarmuła, Bydgoszcz 2016.

Szczutkowska J., Polityka kulturalna PRL w dziedzinie kinematografii w latach 70., Bydgoszcz 2014.

Szczutkowska J., Współpraca kulturalna Polski z Jugosławiq $w$ dziedzinie kinematografii w latach siedemdziesiątych XX wieku, w: Polska i Jugosławia p o II wojnie światowej, red. M. Pavlović, N. Stambolija, A. Zaćmiński, Bydgoszcz 2016.

Szczygielska Z., Nowicki, Warszawa 1984.

Wasiak P., Witerska A., Przestrzeń swobody. Wystawy „zakazanych” artystów z krajów socjalistycznych w Polsce po 1956 roku, w: Bocznymi drogami. Nieoficjalne kontakty społeczeństw socjalistycznych 1956-1989, red. W. Borodziej, J. Kochanowski, Warszawa 2010.

$W$ drodze do sąsiada. Polsko-niemieckie spotkania filmowe, red. A. Dębski, A. Gwóźdź, Wrocław 2013.

Zając J., Zięba R., Polska w stosunkach międzynarodowych 1945-1989, Toruń 2005.

Zajiček E., Film polski. Ekonomika i organizacja produkcji, Warszawa 1983.

Zajiček E., Poza ekranem. Kinematografia polska 1896-2005, Warszawa 2009.

Zwierzchowski P., The reception of Hungarian cinema in Polish film criticism 1945-1989, w: History of European Cinema. Intercultural Perspective, red. B. Zając, M. Pabiś-Orzeszyna, M. Dondzik, Łódź 2015.

Joanna Szczutkowska, adiunkt w Instytucie Historii i Stosunków Międzynarodowych Uniwersytetu Kazimierza Wielkiego w Bydgoszczy. Zainteresowania naukowe: historia kinematografii polskiej, polityka kulturalna PRL, historia i film (histukw@gmail.com).

Joanna Szczutkowska, assistant professor at the Institute of History and International Relations at Kazimierz Wielki University in Bydgoszcz; her research interests cover: the history of Polish filmmaking, the cultural policy of People’s Poland, history and film (histukw@gmail.com). 